\title{
BIOLOGICAL WELFARE AND NUTRITIONAL INEQUALITY IN RURAL MEDITERRANEAN SPAIN: THE IRRIGATED AREA OF VALENCIA, 1859-1939*
}

\author{
MARÍA-ISABEL AYUDA \\ University of Zaragoza ${ }^{\mathrm{a}}$ \\ JAVIER PUCHE \\ University of Zaragoza ${ }^{\mathrm{b}}$
}

\begin{abstract}
This article analyses the biological welfare and inequality of the male population of the irrigated area of Valencia between 1859 and 1939. It studies the effects that the agrarian development process had on physical welfare and the relationship between height and access to land ownership. Height data for conscripts in five municipalities constitute the source for the study. The results reveal that there was a growing trend in the evolution of heights in the irrigated area of Valencia at the beginning of agrarian capitalism. Nutritional inequalities can be observed between farmers and farm workers: land owners were taller than landless labourers. However, this biological inequality diminished over the period under study.
\end{abstract}

Keywords: biological welfare, nutritional inequality, the irrigated area of Valencia, 1859-1939

JEL Code: I10, I14, I15, N33

* Received 18 January 2016. Accepted 21 September 2016. This article has been financed by funds corresponding to the research projects: HAR2013-47182-C2-2-P, ECO2015-65582, ECO2015-71534REDT, ECO2016-74940-P and HAR2016-76814-C2-2-P, financed by the MEC-MICINN; 19512/PI/14, financed by the Fundación Séneca, Agency of Science and Technology of the Region of Murcia; and by the consolidated research groups «Econometric model selection» and "Agri-food economic history (XIXXX centuries)», financed by the Department of Science, Technology and Universities of the Government of Aragon and the European Regional Development Fund. A preliminary version of this article was presented and discussed in the «Workshop on Biological Well-being in Modern Rural Spain», held in Madrid in June 2015 and in the 11th Congress of the Iberian Association of Historical Demography, held in Cádiz in June 2016. The authors thank the valuable comments of the attendees. The authors also thank three anonymous referees and the editor for their useful comments and suggestions, and wish to express their thanks to Salvador Calatayud, José Miguel Martínez Carrión, Vicente Pinilla and Javier Silvestre for their comments during the writing of this article.

a Department of Economic Analysis, Faculty of Economics and Business Studies, University of Zaragoza, Gran Vía 2, 50005, Zaragoza, Spain. mayuda@unizar.es

$\mathrm{b}$ Department of Applied Economics and Economic History, Faculty of Economics and Business Studies, University of Zaragoza, Gran Vía 2, 50005, Zaragoza, Spain. jpuche@unizar.es 


\section{RESUMEN}

Este artículo analiza el bienestar y la desigualdad biológica de la población masculina del regadío valenciano entre 1859 y 1939. Estudia los efectos que el proceso de desarrollo agrario tuvo en el bienestar físico, y la relación entre estatura y acceso a la propiedad de la tierra. Los datos de estatura de los mozos de cinco municipios constituyen la principal fuente utilizada. Los resultados revelan que la evolución de las estaturas en las áreas del regadío valenciano fue creciente en los comienzos del capitalismo agrario. Se observan desigualdades nutricionales entre campesinos con y sin tierras: los primeros eran más altos siempre que los jornaleros sin tierras. Sin embargo, la desigualdad biológica tendió a disminuir durante el periodo de estudio.

Palabras clave: bienestar biológico, desigualdad nutricional, regadío valenciano, 1859-1939

\section{INTRODUCTION}

Over the last four decades, anthropometric history has studied the changes in human welfare based on height and the construction of health indices, analysing the complex relationships between economic growth and the biological welfare of communities in the last three centuries (Komlos 2009; Steckel 2009; Fogel et al. 2011). Spanish historiography has made significant progress in recent years (Martínez-Carrión 2002a, 2014; Martínez-Carrión and MorenoLázaro 2007; María-Dolores and Martínez-Carrión 2011; Spijker et al. 2012; Ayuda and Puche 2014; Martínez-Carrión 2016; Puche and Cañabate-Cabezuelos 2016; Pérez-Castroviejo 2016). Although significant achievements have been made, a more in-depth statistical study of welfare is required, particularly with respect to biological inequality in the Spanish rural community (in 1900 the Spanish agricultural sector still employed 60.7 per cent of the active population).

The pioneer study in this field referred to the region of Murcia (MartínezCarrión 1986), and was followed by others focussed on other geographical regions of Spain, such as rural Catalonia, eastern Andalusia, Castile-Leon and Madrid (Cámara 2009; Garcia-Montero 2009; Hernández and Moreno-Lázaro 2009; Moreno-Lázaro and Martínez-Carrión 2009; Ramon-Muñoz 2009) and on Spain as a whole (Beltrán 2015). All of them reveal that the liberal reforms and the beginnings of agricultural capitalism in the mid- $19^{\text {th }}$ century did not lead to the improvement of the biological living conditions of the Spanish rural population. The privatisation of communal lands in some regions (e.g.in rural eastern Andalusia) did not have positive effects, increasing inequality within rural communities.

The diversity characterising the Spanish agricultural sector at the end of the $19^{\text {th }}$ century, due to the land tenure system, the crop and livestock 
farming systems, the techniques used, the levels of capitalisation, the unequal presence of irrigation, the yields obtained and the type of land or the climatic conditions, indicate that a more in-depth study of the relationships between biological welfare and agricultural growth in rural Spain is required. This article, which analyses the height of males in irrigation areas in rural Valencia between the mid- $19^{\text {th }}$ century and the mid- $20^{\text {th }}$ century, represents a contribution in this direction.

In this context, this study has a double objective: first it evaluates the impact of agricultural growth on the biological standard of living experienced in the irrigated areas of Valencia between the mid-19 $9^{\text {th }}$ century and the mid- $20^{\text {th }}$ century; and second, it calculates how this process affected the inequality in the biological welfare of the population engaged in agriculture, distinguishing between farmers and farm workers.

The new institutional framework that emerged from liberalism and the boost of the international markets gave rise to the growth of intensive crop farming in the irrigated areas of Spain. Therefore, it is necessary to analyse the impact of this growth model based on intensive agriculture and exports on biological welfare and health, and the extent of the socio-nutritional inequalities within the rural communities. Until well into the $20^{\text {th }}$ century, land ownership was generally considered as the principle expression of social inequality within rural communities (Garrabou et al. 2014), and in the Valencian agricultural sector small and medium-sized farms predominated over large properties ${ }^{1}$. In this study we analyse the average height of the rural conscripts in accordance with their access to land ownership. We have divided the individuals of the sample into two social classes in accordance with the social classification of the primary sector in HISCLASS ${ }^{2}$; farmers and farm workers. Although the HISCLASS classification divides primary sector workers into three groups (farmers, lower-skilled farm workers and unskilled farm workers), we have joined the latter two into one group which we have called farm workers, as our sources do not enable us to make this distinction.

The principal sources of data for this study are the height data corresponding to 14,199 conscripts engaged in agricultural activities (of which 10,493 were

\footnotetext{
1 The proportions given by the engineer Pascual Carrión who wrote the first Agricultural Reform Project during the Second Republic, are: small owners 57\%, medium owners 27\% and large owners $16 \%$, Carrión (1973, p. 107).The data drawn from another recent study confirm the predominance of landowners and tenants in the eastern coastal region of Spain: 55.3\% in 1890; 61.9\% in 1910; and 73.8\% in 1930 (Carmona, et al. 2015).

2 HISCLASS (Historical International Social Class Scheme) is based on HISCO, a historicised version of the International Labour Organization's 1968 International Standard Classification of Occupations (ISCO). HISCO and HISCLASS were created by researchers associated with the International Social History Institute in Amsterdam. HISCO is an occupational classification system providing a list of 1,600 occupations. HISCLASS transforms these occupations into a convenient number of socio-occupational categories by means of a set of theoretical and fixed criteria. The main dimensions of the HISCLASS socio-occupational categories are the manual/non-manual division, the skill level and the economic sector, Silvestre et al. (2015) and Leeuwen and Maas (2011).
} 
farmers, and 3,706 were farm workers), who were measured in five municipalities of the eastern part of Valencia where irrigated farming was developed, at least after the mid- $19^{\text {th }}$ century. This rural sample has been obtained from the 48,841 conscripts of these municipalities during the period of study. A weakness of this rural sample is the limited number of observations for the 1860s and 1870 s as there was less information available regarding the profession of the conscripts compared with the subsequent decades. Therefore, in this article we have used the overall sample of 48,841 conscripts (total population of young men) to analyse the evolution of the average height in the irrigated area of Valencia and the sample of farmers and farm workers to analyse the biological inequality in accordance with their access to land ownership. The results reveal that there was a growing trend in evolution of height in these rural areas over the long term. In contrast to the observations of other rural areas of the Spanish Mediterranean (Martínez-Carrión and Pérez Castejón 2002; Ramón-Muñoz 2009), our results suggest that in the irrigated area of Valencia the beginning of the agricultural changes and the intensification of production in the mid- $19^{\text {th }}$ century did lead to an improvement in the biological welfare of the populations. Our results also reveal nutritional inequalities between the rural groups; the landowners always had higher levels than landless farm workers. It can be deduced that access to landownership became a determining factor of the socioeconomic and biological differences in the traditional agricultural societies. These biological differences have also been documented in other Spanish rural areas, such as south-east Spain (Martínez-Carrión and Pérez-Castejón 2002).

Throughout the second half of the $19^{\text {th }}$ century and the first-third of the $20^{\text {th }}$ century, as in other rural Mediterranean parts of Spain, the production systems in Valencia's agricultural sector underwent a remarkable modernisation and intensification process. This occurred in parallel with the progressive integration of the region's agricultural sector into the international economy within the context of the first globalisation process, due particularly to the growing export orientation of the economy. The region of Valencia, like other eastern and southern regions of Spain, gained comparative advantages by specialising in certain crops, such as citric fruits, rice, vegetables, olives and grapes. This enabled it to extend its exporting capacity and food supply to the national and international markets. This agro-export model was based, in turn, on: the widespread use of irrigation, the early incorporation of inorganic fertilisers, the adoption of crops that generated high physical and monetary yields ${ }^{3}$ and the predominance of skilled manual labour in agricultural tasks that were difficult to mechanise. Furthermore, the agri-food sector experienced a significant diversification and modernisation process and a considerable

${ }^{3}$ In the Spanish context, the agricultural product of the region of Valencia was superior to the Spanish average: in particular, the province of Valencia had the highest land productivity indices of the country in 1931 and was ranked second in terms of agricultural labour productivity (Simpson 1994). 
increase in its production capacity (Garrabou 1985; Piqueras 1985; Mateu and Calatayud 1996; Calatayud 2001; Calatayud and Millán 2010).

The study is structured into five parts. After this introduction, the second section describes the principle changes in production experienced by the irrigated area of Valencia between 1850 and 1930, whereby the region's agricultural sector became integrated into the international markets and the irrigated area oriented a good part of its production towards the market. The third part describes the sources and the sample used in the study together with the methodology applied. In the fourth section, the results are presented. Furthermore, the impact that the process of agricultural growth had on the biological welfare of population in the irrigated area of Valencia is analysed. In addition, biological inequality in accordance with access to land ownership is also addressed. Several models have been estimated for both of these aspects. The final conclusions are drawn in the fifth and closing part of the study.

\section{THE IRRIGATED AREA OF VALENCIA, 1850-1930}

Throughout the $19^{\text {th }}$ century, Spanish agriculture underwent a growth process that was driven both by higher demand due to an expanding domestic market in which some products (such as wheat) received considerable protection, and booming external demand for products such as wine, oil and vegetables from countries in western Europe (Garrabou and Sanz 1985; Pinilla 1995; Gallego and Pinilla 1996). This expansion, however, did not give rise to any significant technological changes because the aridity of most of the Peninsula restricted the adoption of the innovations arising from the Atlantic agricultural revolution.

The agricultural crisis at the end of the century and a new technological supply from the United States gave rise to greater changes in the first-third of the $20^{\text {th }}$ century, with a significant increase in labour productivity (Bringas 2000; Gallego 2001). However, despite this undeniable improvement, in 1935, it was still lower than that of the majority of western European countries (O’Brien and Prados 1992, pp. 530-531). Spanish agriculture required a large workforce, not because of the farmers' resistance to change, but due to the low level of development of industrial activities which gave the sector significant weight in the economy (Silvestre 2005). The agricultural sector was characterised by the high price of capital and the low price of labour, which hindered a more profound technological change (Clar and Pinilla 2009).

Within this context, the agricultural sector of the Mediterranean coastal area, particularly in the province of Valencia, had specialised in vegetables which incurred relatively low comparative costs. The specialised agriculture of the Spanish Mediterranean area became integrated into international markets and experienced significant development (Garrabou 1985, Pujol et al. 2001; 
Pinilla and Ayuda 2009, 2010; Ramon-Muñoz 2013). The irrigated area of Valencia developed considerably at the end of the $19^{\text {th }}$ century and during the first-third of the $20^{\text {th }}$ century and Spain gained significant weight in international markets in terms of these products (Garrabou 1985; Piqueras 1985, 1999; Garrabou and Pujol 1988; Calatayud 2001; Pinilla and Ayuda 2009; Calatayud and Millán 2010).

From the 1850s and after the culmination of the crisis of trade specialisations which began in the $18^{\text {th }}$ century (barrilla plant, silk and later, hemp), the Valencian agricultural sector began to cultivate a new wave of crops for domestic and international markets. Although the expansion of vine-growing activities was mainly concentrated in rainfed areas, in the long term, agricultural growth in the region of Valencia was based on irrigated farming. In 1922, this intensive farming represented a quarter of the cultivated area, but if we examine the value of production, in 1931, fruit and vegetables represented 67 per cent (Calatayud 2001, p. 166; Calatayud and Millán 2010, p. 213). The irrigated area of Valencia was very diverse which gave it numerous production options. This means that we must consider the different specialisations, each with their own specific characteristics, as the studies carried out indicate that from the end of the $19^{\text {th }}$ century, there was a trend that ran in parallel with the concentration of ownership and the consolidation of family ownership. The significant development of the irrigated area of Valencia was not only based on the new agricultural bourgeois class (Calatayud et al. 1992), but also on small landowners and tenants. The small farms were as profitable or even more so than the medium-sized and large farms (Calatayud 1989a). Far from a cereal monoculture, rice, oranges and a variety of vegetables with a more dynamic demand contributed to the strong boom experienced in the irrigated areas in the second-half of the $19^{\text {th }}$ century and the first-third of the $20^{\text {th }}$ century (Garrabou 1985; Piqueras 1985, 1999; Calatayud 1989b, 2001; Garrido 1999, 2004; Palafox 2001; Pinilla and Ayuda 2008; Calatayud and Millán 2010). Consequently, the region of Valencia increased its exports of horticultural products. Figure 1 shows that this growth was spectacular, multiplying by $\sim 16$ between 1861 and 1913. During the First World War, however, exports experienced a significant decline, but recovered again in the 1920s (Piqueras 1985, 1999).

As a result of this commercial dynamism, Valencian exports represented a significant percentage of Spain's total exports of Mediterranean horticultural products. The case of oranges, a crop almost exclusively grown in Valencia's coastal areas, was spectacular, but this was not an isolated case (Calatayud 1989a, 1989b; Garrido 1999). In addition to oranges, rice and horticultural products were also significant. The latter, although covering only 10 per cent of the cultivated land, had an important qualitative weight. In around 1930, vegetable crops formed a highly significant part of Valencia's agricultural sector and in many aspects were relevant for the economy: the income generated (including currency for exports), the labour employed and the ties 
FIGURE 1

AVERAGE HEIGHT IN THE IRRIGATED AREA OF VALENCIA AND VOLUME INDEX OF VALENCIAN EXPORTS OF HORTICULTURAL PRODUCTS (ORANGES, ONIONS AND RAISINS) AT 1910 PRICES $(1861=100)$, BIRTH COHORTS OF 1861-1920

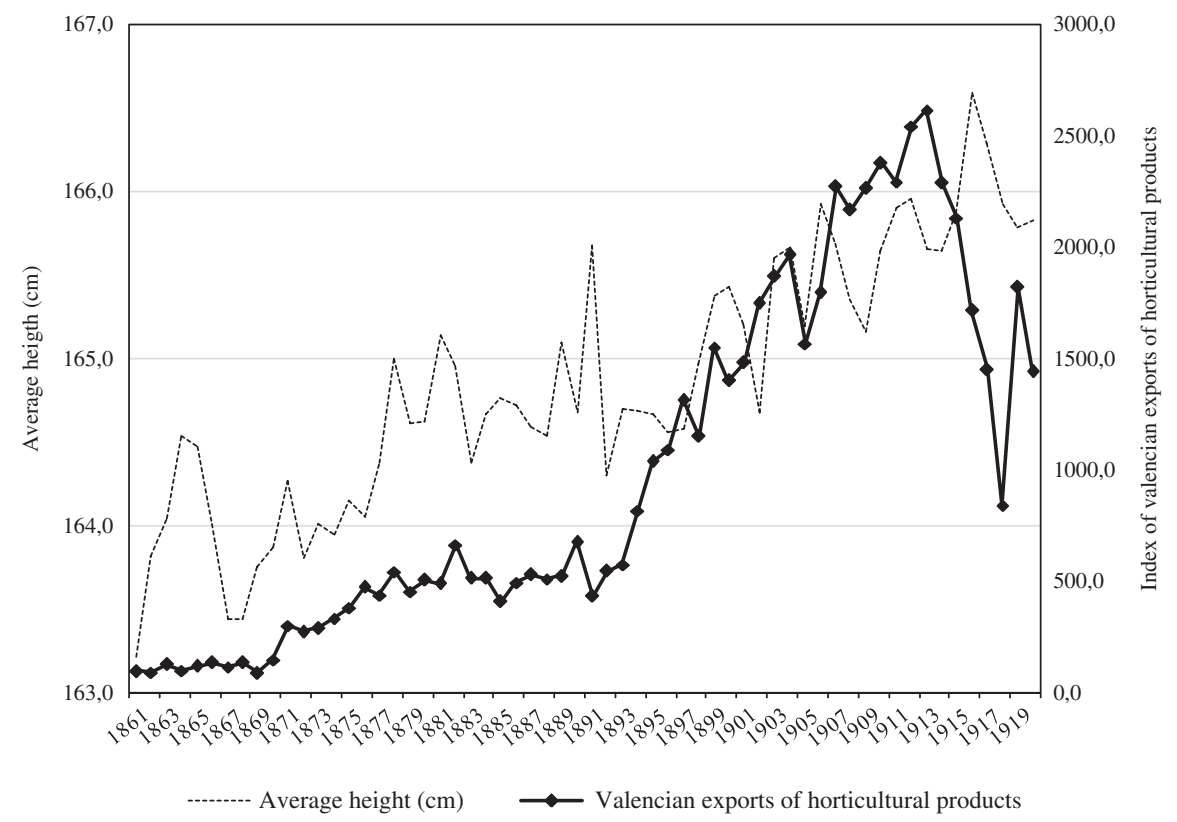

Note: 48,841 conscripts.

Source: Conscription and call-up records; historical municipal archives from Valencian municipalities composing the anthropometric sample. The amounts exported have been drawn from Piqueras (1985, pp. 229-230) and the prices of the different products from Gallego and Pinilla (1996).

with other associated activities. In addition, the production of vegetables consolidated one of the most characteristic areas of rural Valencia, la huerta (orchard) ${ }^{4}$ (Calatayud 2001; Calatayud and Millán 2010).

\section{DATA AND METHODOLOGY}

In order to address the objectives described, this study analyses the height data of 14,199 conscripts engaged in agricultural activities, corresponding to the cohorts born between 1859 and 1939. These were the generations which carried out their military service between 1879 and 1960. The height data

\footnotetext{
${ }^{4}$ Irrigated land used for growing legumes, vegetables and fruit trees.
} 
and other variables of interest (level of education, place of birth, appeals in order to be declared exempt from military service, and, most of all, access to land ownership) are drawn from the local military recruitment series of five municipalities in Valencia which, at least from the mid- $19^{\text {th }}$ century, were engaged in the intensive crop cultivation characteristic of irrigated farming (Figure 2). Several criteria have been considered in the selection of the municipalities: the characterisation of the agricultural growth model based on its product specialisation; the geographical location and restricting environmental conditions and the availability of long-term local military recruitment series. Based on these criteria, the five towns selected were: Villarreal (province of Castellón), Alzira, Sueca, Gandía (province of Valencia) and Pego (province of Alicante).

Villarreal is located in the region of La Plana Baja. It developed a specialisation in oranges cultivated for export very early on (from the 1820s). The main players in the expansion of citric fruit cultivation, which intensified from the 1870s, were the small landowners who planted orange trees in their groves $^{5}$ (Garrido 1999, 2004). In Alzira (Ribera Alta), however, the growth of orange cultivation was due to the landlords, who, in the mid-1 $19^{\text {th }}$ century, focussed on marginal carob and olive grove areas, while the orchards were used for crops for self-consumption and to be sold on the market (vegetables, tubers and bulbs). The new crop incorporated into the intensive agriculture of the groves in Júcar stimulated a high demand for paid labour which was covered partly by families who had small plots of land (Calatayud 1989b; Garrido 1999; Calatayud and Millán 2010). The expansion of orange crops across non-irrigated areas which were watered with groundwaters, extended to other municipalities of Valencia, such as Gandía (La Safor) and Pego (Marina Alta). In both towns, the importance of irrigation reinforced the leading role played by small farms with their intense specialisation in vegetable cultivation (Calatayud and Millán 2010). The stimulus from urban and international markets was decisive for the growth of irrigated crops. The final municipality selected is Sueca, which is intensely specialised in rice and which has highly defined environmental characteristics. Rice was the intensive crop with the most weight in the irrigated area of Valencia for the whole of the $19^{\text {th }}$ century. This crop was able to supply the annual peasant self-consumption and also provide a surplus to be sold on the market. It had a high output per unit area and experienced a growth phase until the $1870 \mathrm{~s}^{6}$. After the difficulties of the $1880 \mathrm{~s}$, and despite tariff protection from 1891, rice underwent a technical improvement process which translated into a recovery of profitability, an increase in yields (due to the use of chemical fertilisers and progress made in seed selection) and a growth in exports

5 In 1882, the percentage of the irrigated area of Villareal covered with orange groves was $64 \%$ and in 1907 it had risen to $89 \%$ (Garrido 1999, p. 206).

6 Between 1840 and 1880, the rice-growing area in Sueca increased from 44,390 Hn to 70,290 Hn, and in 1922 it covered an area of 83,954 Hn (Calzado 1995, p. 220). 
FIGURE 2

MUNICIPALITIES ANALYSED
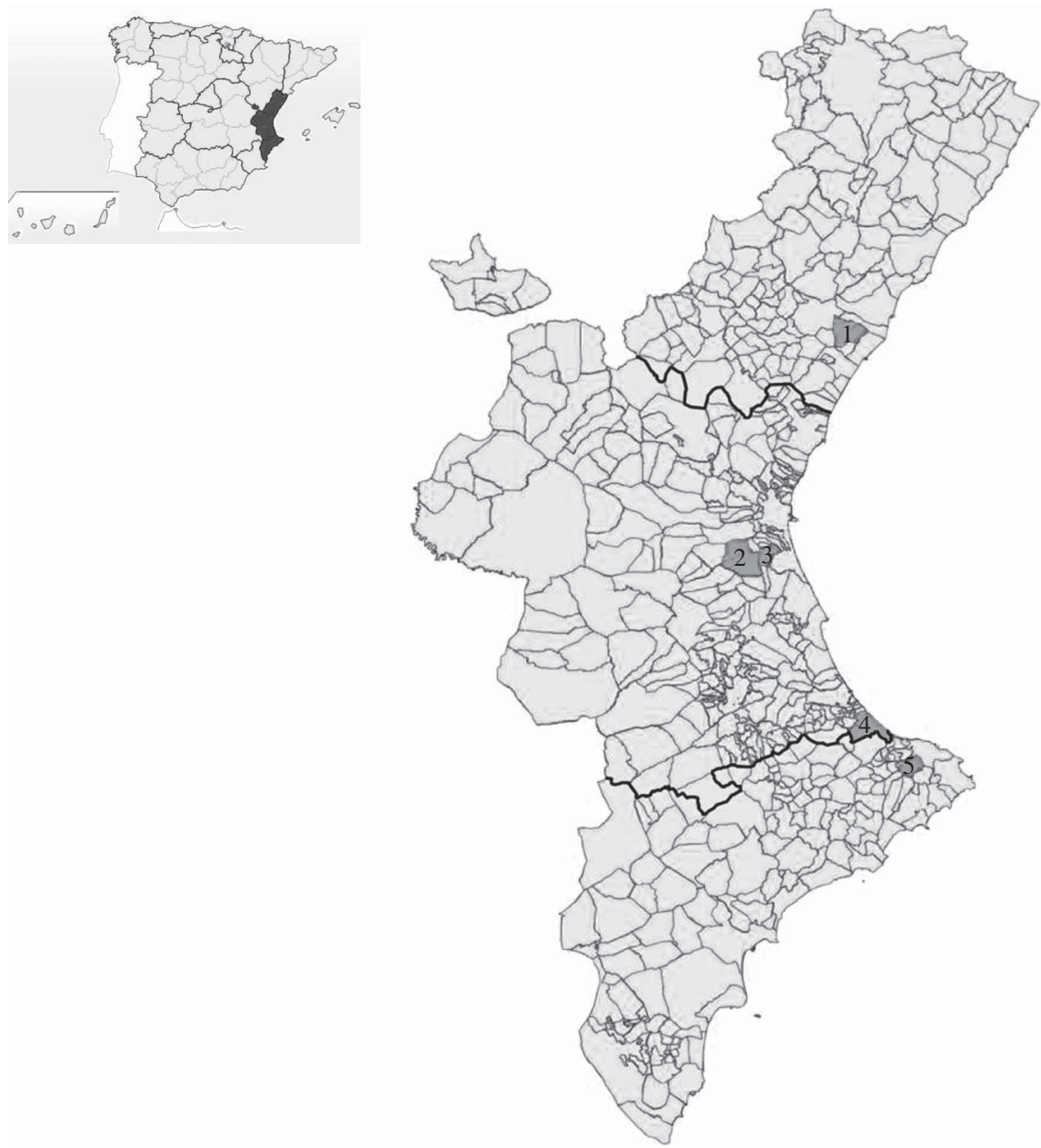

Notes: Municipalities of the sample (district, province and principal production specialisation): (1) Villarreal (Plana Baja, Castellón; oranges); (2) Alzira (Ribera Alta, Valencia; oranges and vegetables); (3) Sueca (Ribera Baja, Valencia; rice and vegetables); (4) Gandía (La Safor, Valencia; oranges, raisins and vegetables); and (5) Pego (Marina Baja, Alicante; rice, oranges and raisins).

Source: Authors' own elaboration.

(Garrabou 1985; Piqueras 1985; Calzado 1995; Calatayud 2001). With greater or lesser intensity, in the five municipalities selected, agroindustrial activities were developed from the end of the $19^{\text {th }}$ century (Piqueras 1999; Calatayud 2001). 
In summary, in our case the five municipalities selected represent different areas of rural Valencia which adapted their production structure, within a context of agricultural specialisation, to external markets.

Although in 1900 all of the municipalities analysed-except for Pegohad populations of $>10,000$ inhabitants, they were not urbanised until the mid- $20^{\text {th }}$ century. They were «agro-towns» as the majority of their inhabitants were employed in the agricultural sector (Martínez-Carrión and Moreno-Lázaro 2007; Ayuda and Puche 2014).

To analyse the biological inequality in accordance with access to property ownership, we have used the anthropometric rural sample of 14,199 conscripts who declared that they were employed in production activities related to agriculture and livestock farming (Table 1). The number of conscripts who declared themselves to be land-owning farmers ${ }^{7}$ is 10,493 (73.9 per cent of the sample), of whom 9,503 (90.6 per cent) were born and measured in the same municipality as those making up the sample ${ }^{8}$. On the other hand, the number of conscripts who declared themselves to be landless farm workers ${ }^{9}$ is 3,706 (the remaining 26.1 per cent of the sample), of whom 3,131 (84.5 per cent) were born and measured in the same municipality as those who made up the sample (Table 1). The possibility that this rural sample is biased in some way cannot be ruled out, as we do not have information about the individuals who may have emigrated before being measured in the municipalities analysed in this study. However, it can be confirmed that for our case this bias would not be highly relevant, because as the intensive agriculture in the region of Valencia offered greater job opportunities and required more labour and capital, there was a low incidence of emigration among the population of the irrigated area of Valencia ${ }^{10}$. This was related to the development of small and medium-sized farms which were more prosperous in terms of employment and wealth in contrast to the poverty of the farm workers of other Spanish agricultural regions (Martínez-Carrión 2002b, p. 30). The breakout of the First World War gave rise to an increase in migrations from the irrigated area of Valencia which was much affected by the international situation and the fall in its main agricultural exports (Nicolau 2005, p. 92) ${ }^{11}$.

7 Landowning farmers are all those who owned or leased lands, who worked or cultivated the land directly or who had control over agricultural production irrespective of the size of the farm.

8 Immigrants are considered as all conscripts born in a different municipality to where they were measured.

9 Landless farm workers are all those who were unspecialised and who worked for a daily wage in the different agricultural tasks and who did not own or lease land or have any type of control over the agricultural production.

${ }^{10}$ Comparatively, the people from the rain-fed area of Valencia emigrated more. Part of these net outflows corresponded to the wine growing areas which were highly affected by the phylloxera crisis at the beginning of the $20^{\text {th }}$ century (Bonmatí 1989).

11 A comparison with the data of the immigrants to the city of Barcelona, a major destination of Valencians, in 1930, reveals that the population from these municipalities in this city represented only $2.6 \%$ of the Valencians residing there, and their weight of the total population of the region of Valencia in the same year was $4.8 \%$ (Silvestre et al. 2015). 
TABLE 1

RURAL SAMPLE CHARACTERISTICS, BIRTH COHORTS OF 1859-1939

\begin{tabular}{|c|c|c|c|c|c|}
\hline & & Cases & \multicolumn{3}{|c|}{ Average height (SD) } \\
\hline & Independent variables & Farmers & Farm workers & Farmers & Farm workers \\
\hline Total & & 10,493 & 3,706 & $165.1(6.4)$ & $163.9(6.5)$ \\
\hline \multirow[t]{5}{*}{ Towns } & Alzira & 2,434 & 2,329 & $164.2(6.3)$ & $163.2(6.6)$ \\
\hline & Gandía & 1,336 & 136 & $162.6(7.8)$ & $164.9(6.8)$ \\
\hline & Pego & 331 & 102 & $167.8(5.5)$ & $168.6(6.4)$ \\
\hline & Sueca & 2,036 & 397 & $165.9(5.9)$ & $163.7(6.1)$ \\
\hline & Villarreal & 4,356 & 742 & $165.8(5.9)$ & $165.4(5.8)$ \\
\hline \multirow[t]{8}{*}{ Birth decade } & 1860 & 914 & 529 & $161.7(6.9)$ & $161.7(6.6)$ \\
\hline & 1870 & 1,102 & 576 & $161.6(7.1)$ & $161.8(6.8)$ \\
\hline & 1880 & 1,761 & 528 & $164.6(6.2)$ & $163.7(6.1)$ \\
\hline & 1890 & 1,023 & 368 & $165.7(5.7)$ & $164.6(5.9)$ \\
\hline & 1900 & 539 & 221 & $165.1(5.6)$ & $164.8(6.2)$ \\
\hline & 1910 & 1,000 & 275 & $165.8(5.8)$ & $165.2(5.8)$ \\
\hline & 1920 & 2,253 & 416 & $165.9(5.8)$ & $165.1(6.2)$ \\
\hline & 1930 & 1,901 & 793 & $167.0(5.9)$ & $166.1(6.1)$ \\
\hline \multirow[t]{2}{*}{ Appeals for exemption } & Not exempt & 9,019 & 3,074 & $165.6(5.7)$ & $164.6(5.8)$ \\
\hline & Physical appeals (exempted) & 1,104 & 360 & $162.6(8.5)$ & $163.4(4.5)$ \\
\hline
\end{tabular}


TABLE 1 (Cont. $)$

\begin{tabular}{|c|c|c|c|c|c|}
\hline & & Cases & \multicolumn{3}{|c|}{ Average height (SD) } \\
\hline & Independent variables & Farmers & Farm workers & Farmers & Farm workers \\
\hline & Social appeals (exempted) & 204 & 118 & $162.6(6.4)$ & $161.9(6.9)$ \\
\hline & No appeal (exempted) & 183 & 159 & $155.5(9.4)$ & $153.5(8.3)$ \\
\hline \multirow[t]{2}{*}{ Literacy } & Illiterate & 3,761 & 1,913 & $163.5(6.8)$ & $162.5(6.8)$ \\
\hline & Literate & 6,732 & 1,793 & $166.0(5.9)$ & $165.5(5.9)$ \\
\hline \multirow[t]{6}{*}{ Place of birth } & Native & 9,503 & 3,131 & $165.2(6.3)$ & $163.8(6.6)$ \\
\hline & Immigrants & 990 & 575 & $164.4(6.4)$ & $164.2(6.2)$ \\
\hline & Immigrants (Valencian region) & 646 & 312 & $164.4(6.6)$ & $164.2(6.2)$ \\
\hline & Immigrants (Andalusia) & 45 & 51 & $163.9(6.6)$ & $163.8(4.9)$ \\
\hline & Immigrants (Castilla-La Mancha) & 96 & 121 & $162.5(5.8)$ & $163.9(6.8)$ \\
\hline & Remaining immigrants & 203 & 91 & $165.3(6.2)$ & $164.9(5.8)$ \\
\hline
\end{tabular}

Note: The average heights have been calculated for the sample of the conscripts engaged in agricultural activities.

Source: Conscription and call-up records; historical municipal archives from Valencian municipalities composing the anthropometric sample. 
Our rural sample has two advantages: first, the data enable us to evaluate the role that access to land ownership had on height and on the biological welfare of the rural populations of the irrigated area of Valencia between the mid- $19^{\text {th }}$ century and the first-third of the $20^{\text {th }}$ century; and second, working with data of an almost homogeneous population implies that our results are probably not affected by cultural or genetic factors which have been pointed out in other studies (Blum 2013).

Although the data corresponding to the Spanish conscripts do not have any truncation problems due to the requirement of a minimum height as in the case of other national armies in the $19^{\text {th }}$ century (Komlos 2004), they do suffer from problems shared by other countries. The most important refers to the successive changes in the age of recruitment which occurred in Spain between 1856 and 1907. From the implementation of «universal» conscription, between 1856 and 1907, the legal age for military service was modified four times: 1856, 20 years of age; 1885, 19 years; 1901, 20 years again; and 1907, 21 years. In order to resolve this problem, we have standardised the heights of the conscripts aged 19 and 20 to the age of $21^{12}$, following the methodology applied by Ramon-Muñoz (2009). According to our calculations, we have increased the height of the conscripts measured at 19 years of age by $1.5 \mathrm{~cm}$ and those measured at the age of 20 by $0.7 \mathrm{~cm}$ (Ayuda and Puche 2014) ${ }^{13}$. Subsequently, and to verify the quality of the data, we have constructed two histograms ${ }^{14}$ which show the frequency distributions of the heights of the conscripts engaged in agricultural activities and measured between 1879 and 1920 (cohorts of the second-half of the $19^{\text {th }}$ century) and between 1921 and 1960 (cohorts of the first-third of the $20^{\text {th }}$ century). In general terms, the histograms show a normal distribution (Figures A1 and A2 of the Appendix).

The anthropometric analysis is divided into two parts. First, the evolution of the biological welfare in the irrigated areas of Valencia has been examined based on the trend in the average height of the conscripts recruited in the five municipalities of the sample and after focussing on the conscripts who were

12 This can be justified because in accordance with studies on physical growth revealing the existence of malnutrition and high child and youth mortality, as was the case in $19^{\text {th }}$ century Spain (Sanz Gimeno and Ramiro Fariñas 2002), physical growth could persist until the age of 21-22. In addition to the health and epidemiological conditions in childhood, there are international studies that have revealed that economic factors, such as wages, can also influence this prolongation of adult height growth (Baten 2000a). The evidence is interesting as it shows that, as well as the childhood years, all anthropometric analyses should also consider the economic circumstances during adolescence. This article has taken this into account.

${ }^{13}$ We have calculated height averages on the basis of the 50th percentile of the three generations of youths who were measured at different ages and close in time (the three first cohorts of our sample) and space (conscripts from the irrigated rural areas in five municipalities in the Valencian region).

14 We also performed several normality tests (Doornick-Hansen, Shapiro-Wilk, Jarque-Bera), but the null hypothesis is rejected for usual significance levels. However, as we have large samples, this is not a problem (Bodenhorn et al. 2013). 
land-owning farmers and landless farm labourers among the birth cohorts of 1859 and 1939. Second, several models have been estimated with the aim of establishing whether being a landowner enabled farmers to exercise contr ol over agricultural production and, in general, whether having a higher level of economic resources influenced physical growth and final height. As control variables we have used the towns where they were measured, the decade of birth, the physical appeals and social type (e.g. economic poverty, family situation or being an orphan) presented by the conscripts to appeal for exemption from military service, the level of literacy and the place of birth. Furthermore, and in order to study the relationship between height and access to land in greater depth, as well as estimating a model for the whole of the period under study, we have estimated another two models for two different sub-periods: the birth cohorts of 1859-99 (6,801 conscripts, 47.9 per cent of the sample) and the birth cohorts between 1900 and 1939 (7,398 conscripts, the remaining 52.1 per cent of the sample). This chronological division is determined by the agricultural crisis at the turn of the century, which constituted a point of inflection in the evolution of the Spanish agricultural sector, and the evolution of Valencian agricultural exports. This crisis, however, did not have a highly significant impact on the agriculture of the Valencian region. The fall in production was much less serious than that of other regions and the structure of crops did not change radically. With respect to agricultural exports, considering that they experienced moderate growth until the beginning of the 1890s, we have decided to integrate the 1890 s into the first sub-period. The beginning of the first of these periods was characterised by the consolidation of new property rights, the emergence of a renewed agricultural elite class made up of the new purchasers of rural assets in the $19^{\text {th }}$ century and the boom in intensive crops. The second stage was characterised by the definitive advance of specialised irrigated crops and the maximum expansion of commercial agriculture (Calatayud 2001).

\section{RESULTS AND DISCUSSION}

\subsection{Evolution of Height in the Irrigated Area of Valencia}

Figure 3 shows the average heights of all the conscripts in the five municipalities making up the sample of the irrigated area of Valencia corresponding to the birth cohorts of the 1860s and 1930s, and the evolution of the coefficient of variation of height $(\mathrm{CV})^{15}$, originally suggested by

15 Here the CVs have been calculated with the standardised heights, although the CV has also been calculated for the raw heights, for homogeneous age groups and the main conclusion is that, for the two cohorts where the individuals are measured at different ages, the CV is higher for those measured at 19 years of age than those measured at 20 years, which are higher than the CV for those measured at 21 years of age. However, most of our recruits were measured at 21 years old, and conscripts were only measured at a different age in the first three decades. 
FIGURE 3

AVERAGE HEIGHT AND HEIGHT INEQUALITY (COEFFICIENT OF VARIATION (CV)) IN THE IRRIGATED AREA OF VALENCIA, BIRTH COHORTS BETWEEN 1860 AND 1930

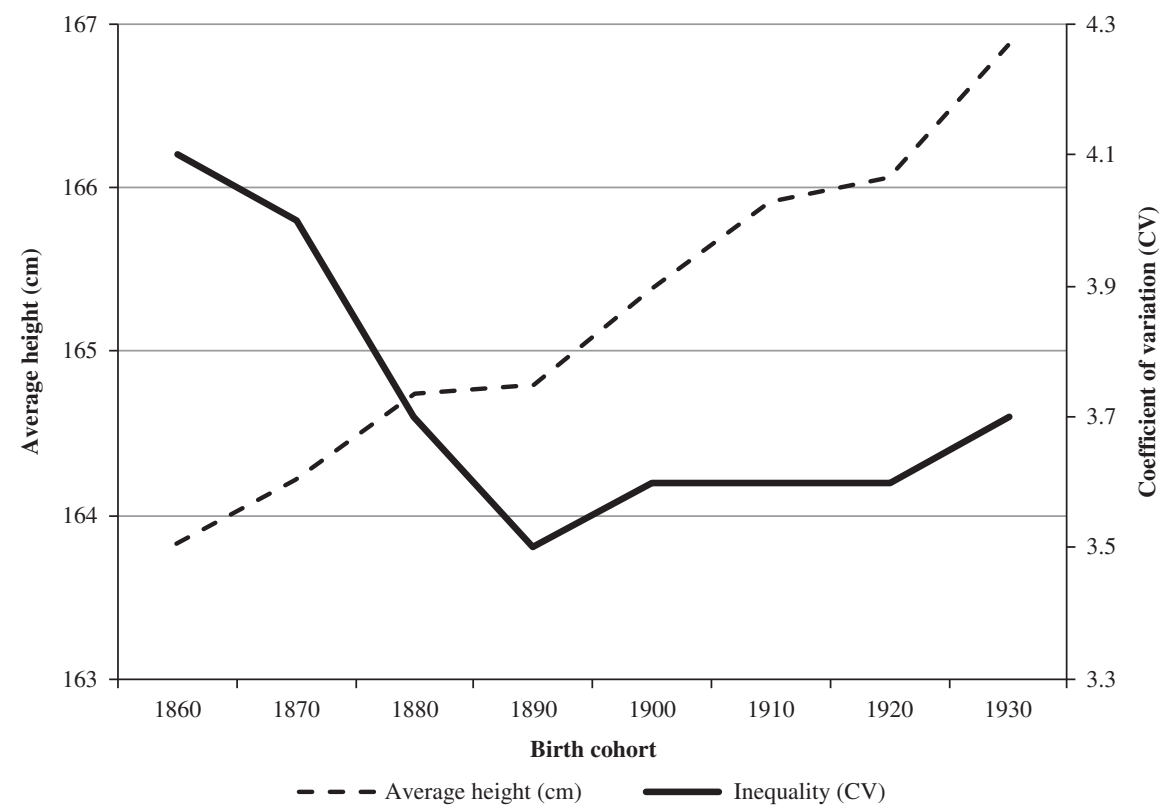

Note: 48,841 conscripts.

Source: Conscription and call-up records; historical municipal archives from Valencian municipalities composing the anthropometric sample.

Baten (2000b) and used in other studies as a indicator of economic inequality (Blum 2013; Ayuda and Puche 2014). The height data reveal, on the one hand, a secular growth trend of biological welfare in the long run, and on the other, the existence of some downturns that altered the growth rhythm of this trend, e.g. during the decade of the 1890s.

In the long term, the average height of the conscripts in the irrigated area of Valencia increased by $3 \mathrm{~cm}$, if we take the averages of the birth cohorts of the 1860 s and 1930 s as a reference, with average height estimates of 163.8 and $166.8 \mathrm{~cm}$, respectively.

The CV suggests that the height inequalities were acute in the mid- $19^{\text {th }}$ century, then they diminished at the end of the century and increased slightly with the birth cohorts of the 1900s and 1930s-the military recruits of the initial years of the Franco regime (Figure 3). In general, the evolution of the average height and the $\mathrm{CV}$ for the irrigated area of Valencia 
was very similar in the analysis of height in accordance with access to land ownership (Figure 4), except in the first two decades, may be due to the bias mentioned in the introduction.

Spanish anthropometric historiography has revealed that the beginning of Spain's modern economic growth in the mid- $19^{\text {th }}$ century did not give rise to an improvement in the living and health conditions of the urban and rural communities (Martínez-Carrión and Pérez-Castejón 2002; Martínez-Carrión and Moreno-Lázaro 2007; Ramon-Muñoz 2009). The results obtained in this study, on the other hand, reveal an improvement in biological welfare in the irrigated area of Valencia in the middle decades of that century. Of the cohorts of the decades of 1860 and 1880, the average height of the population of the irrigated area of Valencia increased by $1 \mathrm{~cm}$ coinciding with the extension of intensive farming and the intensification of production for the market, and all of this in spite of the extension of child labour and the increase in morbidity and mortality rates.

Studies carried out on the agricultural systems that characterised the intensive farming of Valencia have revealed that they offered greater job opportunities and required more labour and capital and that, even though small family-run farms were their driving force, generated higher levels of productivity and wealth than other types of agriculture in Spain (Calatayud 1989a; Simpson 1994; Palafox 2001; Calatayud and Millán 2010). The expansion of intensive agriculture was based on high-yield crops that coexisted with subsistence crops and, most of all, on the growing use of the factor markets (Calatayud 1989a, 2001). As a result, the irrigated area of Valencia generated more prosperity in terms of employment and wealth. In fact, and as previously mentioned, there was a low incidence of emigration among the people from the irrigated area and its economy displayed higher growth rates (Calatayud 2001). Other economic indicators, such as the evolution of agricultural exports, also suggest that the beginnings of the intensive and commercial agricultural model in the irrigated area of Valencia in the mid- $19^{\text {th }}$ century gave rise to an improvement in the biological welfare of its population. In Figure 1 we can observe that while exports of horticultural products began to rise in the 1870 s, reflecting agricultural growth, height also increased, which was a symptom of the improvement of the biological standard of living.

Figure 3 also reveals that the rising trend in biological welfare slowed at the end of the $19^{\text {th }}$ century. Among the birth cohorts of the end of the 1880s and the 1890 s, the average height in the irrigated areas of Valencia stagnated. Considering that during these years the health and epidemiological conditions began to improve, expressed in a fall in the morbidity and mortality rates, particularly among children (Gozálvez 2003), the aforementioned stagnation in height can be explained, in part, by the moderate impact caused by the agricultural crisis at the end of the century. Apart from cereals, this crisis also extended to other crops characteristic of the irrigated area of Valencia, such as 
FIGURE 4

AVERAGE HEIGHT AND HEIGHT INEQUALITY (COEFFICIENT OF VARIATION (CV)) OF FARMERS AND FARM WORKERS IN THE IRRIGATED AREA OF VALENCIA, BIRTH COHORTS BETWEEN 1860 AND 1930
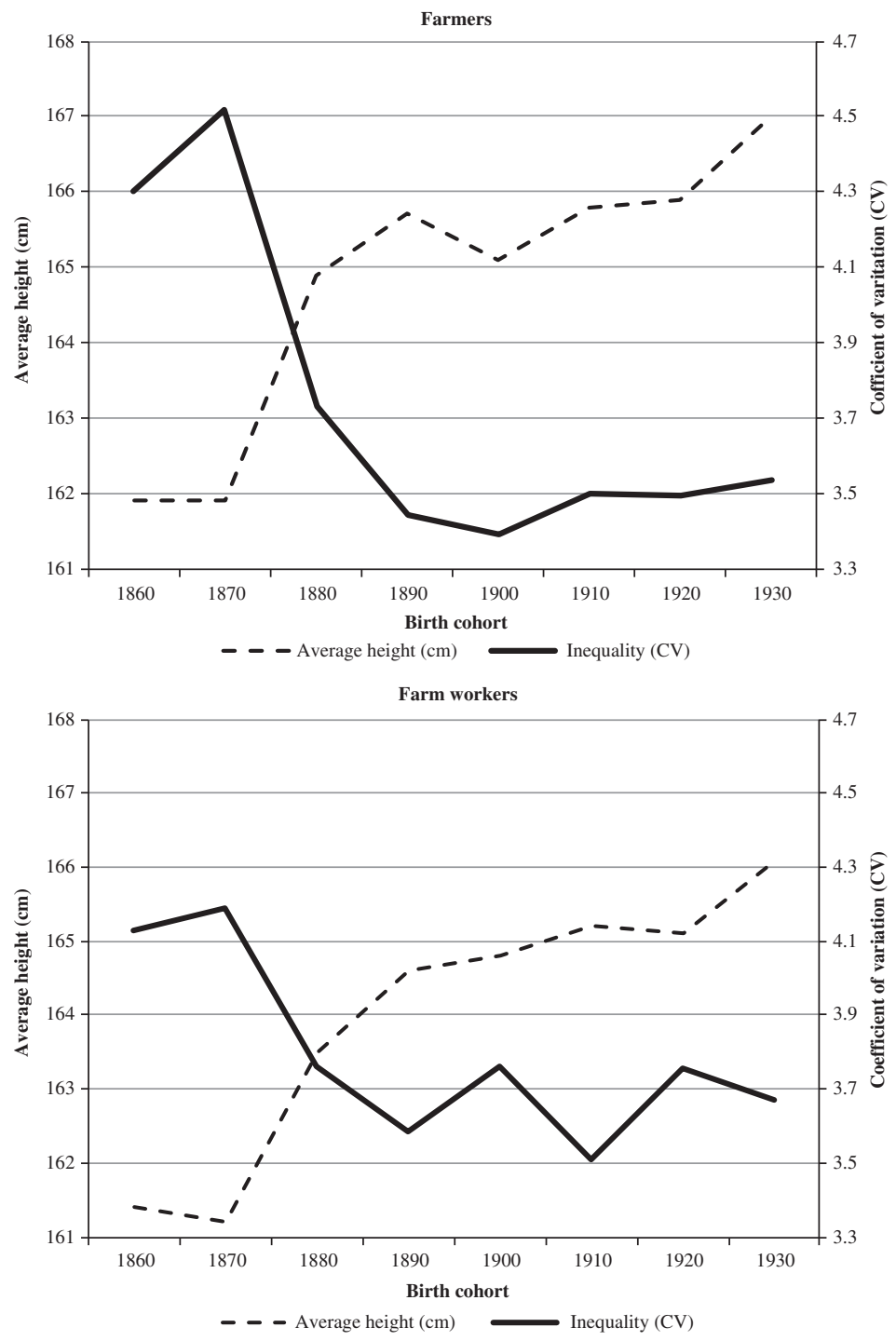

Note: Farmers: 10,493 conscripts; farm workers: 3,706 conscripts.

Source: Conscription and call-up records; historical municipal archives from Valencian municipalities composing the anthropometric sample. 
rice, raisins and, later, oranges (Piqueras 1985), which would have affected the biological welfare of the population of the irrigated area of Valencia. A comparison between the exports of horticultural products and the evolution of average height reveals that, among the cohorts of the middle of the decades of the 1880s and 1890s, the stagnation of exports had a negative effect on the biological welfare of the male population in the irrigated areas of Valencia, which also stagnated.

Figure 3 shows that the conscripts born after the cohorts of the 1900s had higher biological standards of living. The average height of the birth cohorts of the 1900s and 1930s in the irrigated area of Valencia increased by almost $1.5 \mathrm{~cm}$ and the $\mathrm{CV}$ stood at 3.6 per cent. The increase in height indicates that there was an improvement in nutritional status. This anthropometric growth should have been related to a new economic and demographic cycle characterised by the progress made in commercial agriculture, the demand of nearby urban markets, the increase in agricultural exports and the fall in child mortality rates. There were dynamic sectors which reinforced employment and increased the income of farmers. The most spectacular case was that of horticultural products, such as onions (Garrabou 1985; Piqueras 1985, 1999). In general, the situation of the agricultural sector in the region of Valencia was positive, particularly in the irrigated areas, as in addition to export growth there was also greater internal demand arising from the emerging urban markets (such as Valencia) ${ }^{16}$. Again, a comparison between the exports of horticultural products and the evolution of average height reveals that from the beginning of the $20^{\text {th }}$ century, the former had a positive effect on the biological welfare of the male population. So, we can observe that the growth experienced in the heights of the cohorts of the 1900s coincided with the increase in exports in the 1900s and beginning of the 1910s (Figure 1). The health and epidemiological conditions also improved, as shown by regional and local studies, particularly after the decades of the 1890s and 1900s, which report a decrease in overall child ( $<1$-year old) and youth (1-9 years old) mortality and an increase in average life expectancy, all in a context of a decreasing morbidity rate (Ferrater and Terol 1996, pp. 269-271; Gozálvez 2003).

The cohorts of 1910, 1920 and 1930 were the generations that served in the army during the troubled years of the Second Republic, the Civil War and the early years of the Franco regime. Judging from the data represented in Figure 3, and far from what could be expected with respect to the poor economic and supply conditions at the end of the war and during the post-war period ${ }^{17}$, the

\footnotetext{
16 Between 1877 and 1900 the population of the city of Valencia grew from 143,861 to 213,550 inhabitants.

17 In the case of oranges, the mediocre orange season of 1932-33 marked the beginning of a serious crisis for the crop which culminated during the years of the Civil War when the confrontations between the different components of the republican sector with regard to how to organise production, exports and the difficulties generated by the war, led to a slight reduction in
} 
biological welfare of the conscripts of the irrigated area of Valencia improved. Even when hunger and poverty should have constituted the way of life for a considerable part of Valencia's population at that time, the structure of land ownership in some areas (irrigated areas) and the good rhythm of agricultural exports after the 1950s were factors that may explain why the situation for the conscripts in this region differed from the general situation in the rest of Spain (Palafox 2001; Clar et al. 2016). In general terms, the rural areas, due to the greater possibilities of accessing basic foods, enjoyed relatively higher biological standards of living than the urban centres during the initial years of the Franco dictatorship (Ayuda and Puche 2014).

During the period of time analysed, economic inequality (height inequality measured with the coefficient of variation) diminished with average biological well-being (average height): the average height of the population increased by $3 \mathrm{~cm}$ throughout the period, while the coefficient of variation decreased by 0.4 , indicating that height inequality declined (Figure 3). This was also the case for the two socioeconomic groups, farmers and farm workers (Figure 4).

To finish this section, we will analyse the average heights of the conscripts from the five selected municipalities (Figure 5). In general terms, and consistent with the findings of other provincial studies (Heyberger 2007), differences may be observed between the heights of the different municipalities within an overall long-term upward trend ${ }^{18}$. The local differences in average height, which were acute in the mid- $19^{\text {th }}$ century, decreased among the cohorts of the beginning of the $20^{\text {th }}$ century, probably due to economic progress and improvements in healthcare experienced by the five towns as a result of agricultural growth and the fall in morbidity and mortality rates, and increased again during the early years of the Franco regime.

\subsection{Height and Inequality in Accordance with Access to Land Ownership}

Was there biological inequality between landowners and landless farmers? Did the access to land ownership affect final height? Table 1 and Figure 6 show

\footnotetext{
(footnote continued)

foreign sales. In the 1940s, Franco's autarchic policy and its effects on the scarcity of currency with which to supply the inputs necessary to maintain the activity negatively affected the most dynamic sector of Valencia's economy. The modernisation process suffered a clear stagnation and not only in the citrus sector. The maximum levels of production obtained during the pre-war period in 1929 would not be reached again until 1960, Piqueras (1999) and Palafox (2001).

18 This upward trend began in the 1870s, although in rural Valencia some municipalities suffered the negative impact of the First World War. In the case of France, Heyberger (2007) records how Brie (a rural town specialised in cereal crops) suffered the negative impact of the agricultural depression of the last-quarter of the $19^{\text {th }}$ century. In both cases, a positive correlation is observed with some economic indicators. For example, in Limousin (a rural municipality also specialised in cereal crops), the annual height of the conscripts is positively correlated with the weight of cattle. In our case, we can observe that the annual height of conscripts is positively correlated with the exports of horticultural products from the cohorts born in the mid- $19^{\text {th }}$ century.
} 
FIGURE 5

AVERAGE HEIGHT IN FIVE MINICIPALITIES IN THE IRRIGATED AREA OF VALENCIA, BIRTH COHORTS BETWEEN 1860 AND 1930

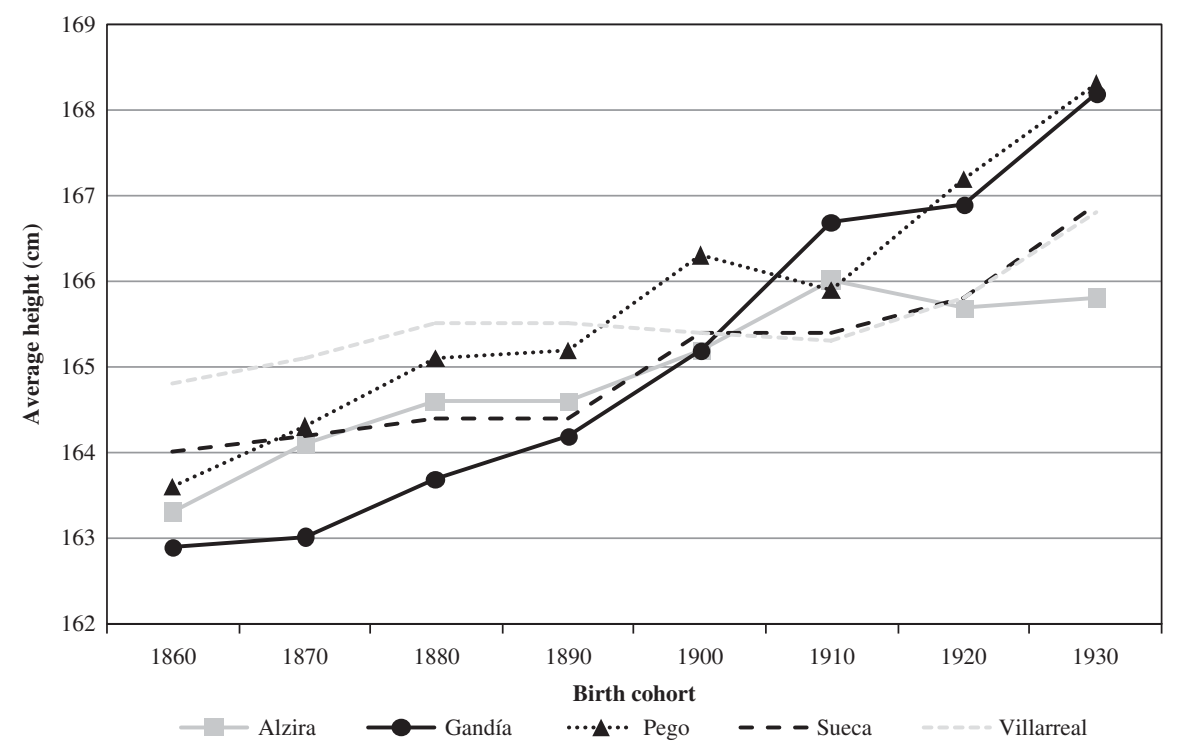

Note: 48,841 conscripts.

Source: Conscription and call-up records; historical municipal archives from Valencian municipalities composing the anthropometric sample.

the contrasts in the average height of the rural conscripts of the irrigated area of Valencia in accordance with their access to land ownership among the cohorts born between the 1860s and 1930s. The results reveal that landowning farmers were always taller than landless farm workers, although they did not grow much more over time. Between the two dates, landowners and tenants grew by $4.8 \mathrm{~cm}$ and farm workers by $4.4 \mathrm{~cm}$. The differences in height were very small in the mid- $19^{\text {th }}$ century, they increased at the end of the century (generations who did their military service during the 1900s and 1910s, in the final phase of the first wave of globalisation) and reduced relatively during the first-third of the $20^{\text {th }}$ century. This reduction in inequality was more evident among the cohorts of the 1900s and 1910s, probably due to the progress made in the redistribution of income as a result of the developments in collective bargaining, particularly during the early years of the Second Republic (1931-33). In contrast, the height differences increased again, affecting the cohorts born in the 1920s and 1930s. This could be due to the negative effects of the Civil War, and particularly, Franco's autarchy, which gave rise to an increase in poverty and inequality among the most disadvantaged social groups. 
FIGURE 6

AVERAGE HEIGHT OF FARMERS AND FARM WORKERS IN THE IRRIGATED AREA OF VALENCIA, BIRTH COHORTS BETWEEN 1860 AND 1930.

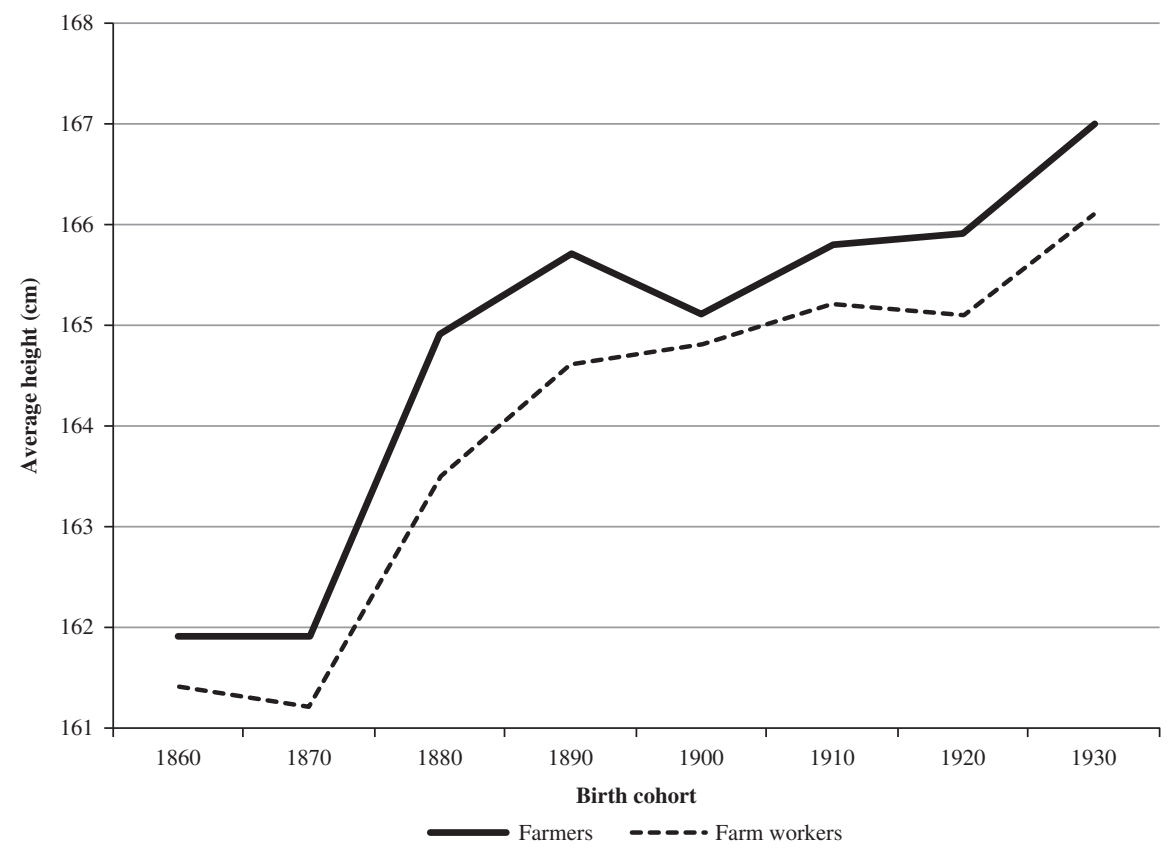

Source: Conscription and call-up records; historical municipal archives from Valencian municipalities composing the anthropometric sample.

In Table 2, we can see the results of the ordinary least square estimates, robust to heteroskedasticity, of three models: the first refers to all the conscripts engaged in agricultural activities (14,199 rural conscripts), the second corresponds to farmers $(10,493$ conscripts $)$ and the third to farm workers ( 3,706 conscripts), with the objective of identifying possible causes of biological differences between the two rural groups. The dependent variable is the height standardised at 21 years (in centimetres) and the explanatory variables are shown in the first column. The second and third columns show the estimated coefficients (Coeff.) and standard errors (SE), respectively, for the general model; the fourth and fifth columns show the estimated coefficients and standard errors for the farmers model; and the sixth and seventh columns for the farm workers model.

In the general model $(14,199$ conscripts) there is a dummy variable "Farmers», taking the value of 1 if the conscript is a farmer and zero if he is a farm worker, in order to distinguish whether there are differences between these two rural groups. As the «Farmers» dummy variable is positive and 
TABLE 2

REGRESSION RESULTS: DETERMINANTS OF HEIGHT AND SOCIAL INEQUALITY IN THE IRRIGATED AREA OF VALENCIA, BIRTH COHORTS OF 1859-1939

\begin{tabular}{|c|c|c|c|c|c|c|}
\hline & \multicolumn{2}{|c|}{ All } & \multicolumn{2}{|c|}{ Farmers } & \multicolumn{2}{|c|}{ Farm workers } \\
\hline & Coeff. & SE & Coeff. & SE & Coeff. & SE \\
\hline Intercept & $162.8^{* * *}$ & 0.22 & $163.3^{* * *}$ & 0.25 & $163.2 * * *$ & 0.39 \\
\hline \multicolumn{7}{|l|}{ Towns } \\
\hline Villarreal & Ref. & & Ref. & & Ref. & \\
\hline Alzira & $-0.55^{* * *}$ & 0.13 & $-0.33^{* *}$ & 0.16 & $-1.08 * * *$ & 0.29 \\
\hline Gandía & $-1.65^{* * * *}$ & 0.20 & $-1.79 * * *$ & 0.22 & -0.15 & 0.64 \\
\hline Pego & $1.00 * * *$ & 0.30 & $0.64 *$ & 0.33 & $1.94 * * *$ & 0.70 \\
\hline Sueca & $-0.46 * * *$ & 0.15 & $-0.39 * *$ & 0.17 & $-1.05 * *$ & 0.43 \\
\hline \multicolumn{7}{|l|}{ Decade of birth } \\
\hline $1859-69$ & Ref. & & Ref. & & Ref. & \\
\hline $1870-79$ & 0.01 & 0.22 & -0.13 & 0.28 & 0.21 & 0.34 \\
\hline $1880-89$ & $2.06^{* * *}$ & 0.21 & $2.10^{* * *}$ & 0.26 & 1.76 & 0.36 \\
\hline $1890-99$ & $3.16^{* * *}$ & 0.25 & $3.31 * * *$ & 0.31 & $2.43^{* * *}$ & 0.46 \\
\hline 1900-09 & $2.58 * * *$ & 0.28 & $2.56^{* * *}$ & 0.34 & $2.59 * * *$ & 0.55 \\
\hline 1910-19 & $2.64 * * *$ & 0.26 & $2.50 * * *$ & 0.31 & $3.01 * * *$ & 0.49 \\
\hline $1920-29$ & $2.79^{* * *}$ & 0.22 & $2.73^{* * *}$ & 0.27 & $2.86^{* * *}$ & 0.44 \\
\hline $1930-39$ & $3.51 * * *$ & 0.23 & $3.58^{* * *}$ & 0.29 & $3.27 * * *$ & 0.40 \\
\hline \multicolumn{7}{|l|}{ Appeals for exemption } \\
\hline Declared fit to serve & Ref. & & Ref. & & Ref. & \\
\hline Physical appeals (exempted) & $-2.81^{* * *}$ & 0.21 & $-3.22 * * *$ & 0.25 & $-1.57 * * *$ & 0.41 \\
\hline
\end{tabular}




\begin{tabular}{|c|c|c|c|c|c|c|}
\hline Social appeal (exempted) & $-1.80^{* * * *}$ & 0.36 & $-1.59^{* * * *}$ & 0.45 & $-1.99 * * *$ & 0.62 \\
\hline No appeal (exempted) & $-9.50^{* * * *}$ & 0.44 & $-8.86^{* * * *}$ & 0.62 & $-10.41^{* * * *}$ & 0.59 \\
\hline \multicolumn{7}{|l|}{ Education } \\
\hline Illiterate & Ref. & & Ref. & & Ref. & \\
\hline Literate & $0.86^{* * * *}$ & 0.13 & $0.84^{* * *}$ & 0.15 & $0.69^{* * * *}$ & 0.25 \\
\hline \multicolumn{7}{|l|}{ Place of birth } \\
\hline Natives & Ref. & & Ref. & & Ref. & \\
\hline Imm. (Valencian region) & $-0.65^{* * *}$ & 0.21 & $-0.69 * * *$ & 0.25 & $-0.63^{*}$ & 0.35 \\
\hline Imm. (Cast.-La Mancha) & $-3.03^{* * * *}$ & 0.44 & $-4.14 * * *$ & 0.60 & $-1.77^{* * *}$ & 0.64 \\
\hline Imm. (Andalusia) & $-2.93 * * *$ & 0.61 & $-2.26 * *$ & 0.99 & $-2.65^{* * *}$ & 0.75 \\
\hline Remaining immigrants & $-0.97^{* * * *}$ & 0.35 & $-1.04 * *$ & 0.43 & -0.87 & 0.60 \\
\hline \multicolumn{7}{|c|}{ HISCLASS (Historical International Social Class Scheme) } \\
\hline Farm workers & Ref. & & & & & \\
\hline Farmers & $0.42 * * *$ & 0.12 & & & & \\
\hline Sample size & 14,199 & & 10,493 & & 3,706 & \\
\hline Adjusted $R^{2}$ & 0.16 & & 0.14 & & 0.20 & \\
\hline
\end{tabular}

Notes: Coeff: coefficient.

Dependent variable: height at 21 years, in centimetres.

OLS estimates; SE denotes robust standard error.

$*, * * * * * *$ Statistically significant at $10 \%, 5 \%$ and $1 \%$ levels, respectively

Source: Conscription and call-up records; historical municipal archives from Valencian municipalities composing the anthropometric sample. 
significant, even at the 1 per cent level of significance, we can conclude that there are some differences between these two rural groups, in favour of the farmers $(0.4 \mathrm{~cm})$. We have presented the two other models in order to distinguish between the two rural groups; farmers and farm workers.

The variables used in the estimates can be divided into four groups. The first group is called towns, composed of four dummy variables taking the value 1 if the individual was conscripted in this town and 0 if not, and their coefficients measure the difference between those born in this town and those born in the base town, which is Villarreal. According to our estimates, for the total sample size and for the farmers, Pego is the town with the highest figure for estimated average height and Gandía has the shortest estimated average height, but for the farm workers, the largest estimated differences in height are between those of Pego ${ }^{19}$ and those conscripted in Alzira. The second group is called Decades of birth, composed of seven dummy variables taking the value of 1 if the individual was born in this decade and 0 if not, and their coefficients measure the difference in the average height between those born in this decade and those born in the base decade, which is that of those born between 1859 and 1869, while the rest of the variables remain fixed. According to our estimates, the farmers with and without land in the irrigated area of Valencia born in the decade 1930-39 were, on average, $3.6 \mathrm{~cm}$ and $3.3 \mathrm{~cm}$ taller than the birth cohorts of 1859-69, respectively. (Table 2, Decade of birth, columns 4 and 6).

The third group of variables measures differences in terms of Socio Economic Status (SES), such as the health status, the family situation or the access to educational resources. We can divide this group into two sub-groups of variables. The first sub-group includes the variables called Appeals for exemption where the base group is formed by the conscripts declared fit to serve and three dummy variables; Physical appeals (exempted) which is a variable that takes the value of 1 if the individual is declared exempt for physical appeals and zero if not; Social appeal (exempted) which takes the value of 1 if the individual is declared exempt for social appeals and 0 if not; and No appeal (exempted) which takes the value of 1 if the individual is exempt from doing military service but has not appealed. The second sub-group includes the variables that measure the Educational level of the conscripts. Illiterate constitute the base group and the Literate is a dummy variable taking the value of 1 if the conscript is literate and 0 if not.

19 The estimates of the coefficients of variable Pego are biased upwards as we only have height information for this town for conscripts born in the last two decades. With the exception of the 1890 s, the lack of height data for the previous decades is because there is no information regarding the profession of the conscripts. Nevertheless, comparisons of the local height series (with and without the profession) carried out in previous studies and in Graph 4 reveal that, from the end of the $19^{\text {th }}$ century, the average height of the conscripts from Pego was taller than that of the other municipalities in the sample (Puche 2011, p. 384). 
The main results arising from the estimates are that the farmers with and without land who were excluded from military service due to physical problems were, on average, 3.2 and $1.6 \mathrm{~cm}$ shorter, respectively, than those farmers with and without land declared as fit to serve; those farmers with and without land who were declared exempt from military services due to social causes (family situation of poverty, elderly parents, being an orphan, etc.) were, on average, almost $1.8 \mathrm{~cm}$ shorter, respectively, than their counterparts who were declared fit for service; finally, those farmers and farm workers who were declared exempt from military service without having presented an appeal were, on average, 8.9 and $10.4 \mathrm{~cm}$ shorter, respectively, than those who were declared as being fit (Table 2, Appeals for exemption, columns 4 and 6). Our data reveal that there was a phenomenon that conditioned these strong differences: the high number of conscripts who were exempt due to their short height ${ }^{20}$. In general, it can be deduced that these conscripts came from the most disadvantaged groups of Valencia's rural society. The results are conclusive, as they indicate the decisive influence that health and poverty conditions and problems of physical growth had on biological welfare (Ayuda and Puche 2014).

From the estimates of the coefficients of the variable that measures the level of education we can conclude that the land-owning and landless farmers who were literate were taller on average than those who were illiterate. More specifically, they were almost one centimetre taller (Table 2, Education, column 2). This difference in height between literate and illiterate people is wider among farmers than among farm workers (Table 2, Education, columns 4 and 6). The results of the models confirm that the positive relationship between literacy and height and access to education is related to a higher final average height and greater biological welfare (Martínez-Carrión and Puche 2009; Ayuda and Puche 2014).

The fourth and final group of variables contains those relating to the Place of birth, which, as a base group includes the natives and also four dummy variables to indicate immigrants from different areas. For example, Immigrant (Valencian region) takes the value of 1 if the individual was born in the Valencian region, but in a municipality different to the one where he was measured and 0 if not. From the estimate of their coefficients we can deduce that the place of birth and the unequal levels of economic development are important factors. The farmers with or without land born in the same municipalities as those where they were measured (natives of the sample) were taller than immigrant farmers with or without land, even with respect to immigrants from the same region. The immigrant farmers born in other municipalities in the region of Valencia were, on average, $0.7 \mathrm{~cm}$ shorter than the native farmers (Table 2, Place of birth,

${ }^{20}$ It has been calculated that of the 183 farmers who were declared exempt from military service without making an appeal, 124 were too short to be recruited $(67.8 \%)$, and of the 159 farm workers who were exempt without having made an appeal, 119 were too short (74.8\%). 
columns 4 and 6). The difference is remarkable, particularly if we take into account that some of these immigrant farmers could have been born in one of the five municipalities included in the sample, as well as other rural communities in the region of Valencia. With respect to the latter, it can be inferred that they could have emigrated from rural municipalities with environmental conditions that were relatively worse and with a less advanced agricultural sector. There is less doubt with respect to the comparison carried out between farmers with and without land who were immigrants born in other Spanish regions. The model reveals that the immigrant farmers born in Castilla-La Mancha and Andalusia were shorter, on average, than the farmers from the irrigated area of Valencia, specifically 4.1 and $2.3 \mathrm{~cm}$ shorter, respectively. With respect to the landless farm workers who were immigrants from these two regions in the centre and south of Spain, their average heights were 1.8 and $2.7 \mathrm{~cm}$ shorter, respectively, than those of the landless farm workers in the huertas of Valencia (Table 2, Place of birth, columns 4 and 6).

The econometric evidence corresponds to that observed in the Spanish agricultural historiography, which establishes the existence of different Spanish agricultures in virtue of variables such as the difference in productivity or the structure of ownership, among others (Gallego 1993). In the economic modernisation process, which took place between 1850 and 1930, certain territories clearly gained positions and others lost them to different degrees. The region of Valencia was an unquestionable winner, as it was then one of the most dynamic areas in terms of agriculture and the Spanish economy. Among the undeniable losers were Andalusia and CastillaLa Mancha, which had always remained within the parameters of a typically rainfed agriculture, with a predominance of traditional crops. Our results suggest that these differences were reflected in rural heights.

To end this section, we would like to examine in depth the role that access to land had on the biological welfare of the rural male populations of the irrigated area of Valencia between the 1860s and the end of the 1930s. To do this we have estimated three models in order to compare the influence of the variables analysed on the height of the two rural groups selected, farmers and farm workers, and whether this influence changed in different periods of time. The first estimate refers to the whole period of the study, while the second and third address, respectively, the cohorts born between 1859 and 1899 and between 1900 and 1939 (Table 3).

In Table 3, a single model has been estimated for all of the individuals with the objective of distinguishing the effects of the independent variables on the endogenous variable for the two categories, farmers and farm workers. We have also introduced a dummy variable multiplying each independent variable, Farmers, which takes the value of 1 if the individual is a farmer and 0 if he is a farm worker. If we analyse the first group of independent variables (Town), we can appreciate significative differences between the two periods. In the first period (1859-99), the differences within the same town between farmers and 
TABLE 3

REGRESSION RESULTS: DETERMINANTS OF HEIGHT AND SOCIAL INEQUALITY IN THE IRRIGATED AREA OF VALENCIA, BIRTH COHORTS OF 1859-1939

\begin{tabular}{|c|c|c|c|c|c|c|}
\hline & \multicolumn{2}{|c|}{$\begin{array}{c}\text { Model 1 } \\
(1859-1939)\end{array}$} & \multicolumn{2}{|c|}{$\begin{array}{l}\text { Model } 2 \text { (1859-99) } \\
\text { (first sub-period) }\end{array}$} & \multicolumn{2}{|c|}{$\begin{array}{l}\text { Model } 3 \text { (1900-39) } \\
\text { (second sub-period) }\end{array}$} \\
\hline & Coeff. & SE & Coeff. & SE & Coeff. & SE \\
\hline Intercept & $163.2^{* * *}$ & 0.39 & $163.4^{* * *}$ & 0.52 & $165.7^{* * *}$ & 0.67 \\
\hline \multicolumn{7}{|l|}{ Town } \\
\hline Villarreal & Ref. & & Ref. & & Ref. & \\
\hline Alzira & $-1.08 * * *$ & 0.28 & $-1.17 * * *$ & 0.45 & $-0.75^{*}$ & 0.39 \\
\hline Gandía & -0.14 & 0.65 & $-4.12 * * *$ & 1.25 & 0.33 & 0.69 \\
\hline Pego & $1.95 * * *$ & 0.70 & -2.17 & 1.82 & $2.35 * * *$ & 0.74 \\
\hline Sueca & $-1.04 * *$ & 0.43 & 0.05 & 0.65 & $-1.81 * * *$ & 0.59 \\
\hline Villarreal $\times$ farmers & -1.85 & 1.99 & $3.53 * *$ & 1.64 & -0.89 & 2.23 \\
\hline Alzira $\times$ farmers & -1.10 & 1.97 & $3.84 * *$ & 1.66 & -0.47 & 2.21 \\
\hline Gandía $\times$ farmers & $-3.50 *$ & 2.07 & $4.10^{* * *}$ & 2.04 & -0.80 & 2.31 \\
\hline Pego $\times$ farmers & -3.16 & 2.08 & $4.82 *$ & 2.46 & -2.19 & 2.31 \\
\hline Sueca $\times$ farmers & -1.21 & 2.01 & 2.84 & 1.77 & 0.77 & 2.27 \\
\hline \multicolumn{7}{|l|}{ Decade of birth } \\
\hline $1859-69$ & Ref. & & Ref. & & & \\
\hline $1870-79$ & 0.21 & 0.33 & 0.26 & 0.33 & & \\
\hline $1880-89$ & $1.76^{* * *}$ & 0.36 & $2.04 * * *$ & 0.37 & & \\
\hline $1890-99$ & $2.44 * * *$ & 0.45 & $2.68 * * *$ & 0.51 & & \\
\hline
\end{tabular}


TABLE 3 (Cont.)

\begin{tabular}{|c|c|c|c|c|c|c|}
\hline & \multicolumn{2}{|c|}{$\begin{array}{c}\text { Model 1 } \\
(1859-1939)\end{array}$} & \multicolumn{2}{|c|}{$\begin{array}{l}\text { Model } 2 \text { (1859-99) } \\
\text { (first sub-period) }\end{array}$} & \multicolumn{2}{|c|}{$\begin{array}{l}\text { Model } 3 \text { (1900-39) } \\
\text { (second sub-period) }\end{array}$} \\
\hline & Coeff. & $\mathbf{S E}$ & Coeff. & SE & Coeff. & SE \\
\hline 1900-09 & $2.60 * * *$ & 0.55 & & & Ref. & \\
\hline 1910-19 & $3.00 * * *$ & 0.49 & & & -0.03 & 0.60 \\
\hline $1920-29$ & $2.85^{* * *}$ & 0.44 & & & -0.40 & 0.67 \\
\hline 1930-39 & $3.26^{* * *}$ & 0.39 & & & 0.17 & 0.65 \\
\hline $1859-69 \times$ farmers & -0.31 & 0.49 & -0.38 & 0.63 & & \\
\hline $1870-79 \times$ farmers & -0.66 & 0.47 & -0.91 & 0.58 & & \\
\hline $1880-89 \times$ farmers & 0.02 & 0.45 & -0.92 & 0.55 & & \\
\hline $1890-99 \times$ farmers & 0.56 & 0.51 & & & & \\
\hline $1900-09 \times$ farmers & -0.36 & 0.63 & & & $-1.29 *$ & 0.72 \\
\hline $1910-19 \times$ farmers & -0.83 & 0.51 & & & -0.84 & 0.51 \\
\hline $1920-29 \times$ farmers & -0.44 & 0.43 & & & -0.38 & 0.43 \\
\hline $1930-39 \times$ farmers & & & & & & \\
\hline \multicolumn{7}{|l|}{ Appeals for exemption } \\
\hline Declared fit to serve & Ref. & & Ref. & & Ref. & \\
\hline Physical appeals (exempted) & $-1.56^{* * *}$ & 0.40 & $-2.17 * * *$ & 0.54 & -0.71 & 0.61 \\
\hline Social appeals (exempted) & $-1.99 * * *$ & 0.62 & $-2.61 * * *$ & 0.67 & -0 & 1.49 \\
\hline No appeal (exempted) & $-10.41^{* * *}$ & 0.59 & $-12.56^{* * *}$ & 0.51 & $-2.79 * *$ & 1.42 \\
\hline Declared fit to serve $\times$ farmers & 2.25 & 1.93 & -2.11 & 1.60 & 1.05 & 2.15 \\
\hline Physical appeals (exempted) $\times$ farmers & 0.56 & 1.96 & $-5.22 * * *$ & 1.64 & 0.69 & 2.21 \\
\hline
\end{tabular}




\begin{tabular}{|c|c|c|c|c|c|c|}
\hline Social appeals (exempted) $\times$ farmers & 2.46 & 1.98 & -1.53 & 1.65 & 0.30 & 2.51 \\
\hline No appeal $($ exempted $) \times$ farmers & $3.80^{*}$ & 2.11 & -0.10 & 1.79 & 2.42 & 2.99 \\
\hline \multicolumn{7}{|l|}{ Education } \\
\hline Illiterate & Ref. & & Ref. & & Ref. & \\
\hline Literate & $0.69^{* * *}$ & 0.25 & $0.55^{*}$ & 0.31 & $0.859^{* * *}$ & 0.40 \\
\hline Literate $\times$ farmers & 0.15 & 0.29 & 0.10 & 0.36 & 0.39 & 0.47 \\
\hline \multicolumn{7}{|l|}{ Place of birth } \\
\hline Natives & Ref. & & Ref. & & Ref. & \\
\hline Immigrants (Valencian region) & $-0.62^{*}$ & 0.34 & $-1.47^{* * *}$ & 0.53 & -0.18 & 0.44 \\
\hline Immigrants (Castilla-La Mancha) & $-1.76^{* * *}$ & 0.63 & $-4.88^{* * * *}$ & 1.53 & $-1.48^{* *}$ & 0.65 \\
\hline Immigrants (Andalusia) & $-2.64 * * *$ & 0.74 & -1.27 & 4.20 & $-2.42 * * *$ & 0.74 \\
\hline Remaining immigrants & -0.69 & 0.50 & -1.91 & 1.41 & -0.40 & 0.53 \\
\hline Immigrants (Valencian region) $\times$ farmers & -0.07 & 0.42 & 0.88 & 0.69 & -0.47 & 0.53 \\
\hline Immigrants (Castilla-La Mancha) $\times$ farmers & $-2.06^{* *}$ & 0.96 & & & $-2.07^{* *}$ & 0.98 \\
\hline Immigrants (Andalusia) $\times$ farmers & 0.37 & 1.24 & & & 0.15 & 1.27 \\
\hline Remaining immigrants $\times$ farmers & -0.49 & 0.62 & 0.26 & 1.97 & -0.52 & 0.64 \\
\hline Sample size & 14,199 & & 6,801 & & 7,398 & \\
\hline$R^{2}$ adjusted & 0.16 & & 0.25 & & 0.04 & \\
\hline
\end{tabular}

Notes: Coeff: coefficient.

Dependent variable: height at 21 years, in centimetres.

OLS estimates; SE denotes robust standard error.

$*, * *, * * *$ Statistically significant at $10 \%, 5 \%$ and $1 \%$ levels, respectively.

Source: Conscription and call-up records; historical municipal archives from Valencian municipalities composing the anthropometric sample. 
farm workers were significant in favour of the farmers in four of the five municipalities. However, in the second period (1900-39) these differences were no longer significant. With respect to the first sub-group of the set of variables that measure the effect of the SES (Appeals for exemption), the general model finds hardly any differences in height between the two rural groups in accordance with the appeals, although differences were found during the first sub-period. Of the cohorts between 1859 and 1899, the farmers who were excluded from military service because they had claimed to have physical problems were, on average, $5.2 \mathrm{~cm}$ shorter than the farm workers declared exempt for the same reason (Table 3, Model 2, column 4). But they were not only shorter, they also made more appeals (10.5 per cent as opposed to 2.9 per cent). What factors could explain this difference in height? It could be argued that a proportion of the land-owning farmers who lived during the period 1870-1910 experienced the economic improvements associated with the expansion of intensive and commercial agriculture, but their bodies suffered the effects of the agricultural growth period as a consequence of the intensive use of labour, the intensification of production and a possible relative reduction in food consumption. With respect to the second sub-group of variables which measure the effect of the SES on height (Education), the three models reveal hardly any significant differences in height between the literate land-owning farmers and landless farmers (Table 3, Models 1-3, columns 2, 4 and 6). The same can be observed in the last group of independent variables (Place of birth). However, there is one surprising result: although the coefficient is not highly significant, the immigrant farmers from Castilla-La Mancha were, on average, $2.1 \mathrm{~cm}$ shorter than the immigrant farm workers from the same region (Table 3, Model 1, column 2). In the rest of the immigrant groups there are no significant differences in height between farmers and farm workers.

In summary, from the estimates for the two sub-periods we can observe that in the first sub-period there are some differences between farmers and farm workers but, in the second sub-period the differences between farmers and farm workers were hardly significant which indicates that the inequality observed between these two groups diminished over time.

\section{CONCLUSIONS}

Based on the selection of five municipalities in the region of Valencia engaged in irrigated farming, this article has examined two issues related with the biological standard of living in Mediterranean rural Spain: first, the impact that the expansion of intensive and commercial agricultural and the agricultural growth process had on the physical welfare of the male population between the mid- $19^{\text {th }}$ century and the first-third of the $20^{\text {th }}$ century; and second, the influence that the socioeconomic status, measured in terms of access to landownership, had on the final average height and on the social 
inequality of the rural communities. For both of these objectives the height data of the population of 41,841 conscripts, and a rural sample of 14,199 conscripts engaged in agricultural activities (10,493 farmers and 3,706 farm workers) between 1859 and 1939, have been analysed.

The anthropometric evidence shows that in the long term, the average height in the irrigated area of eastern Valencia increased by approximately $3 \mathrm{~cm}$ among the cohorts born between 1859 and 1939. The balance, in strictly biological terms, was positive. In this sense, one of the most relevant results that we have obtained is that, in contrast to what has been observed in other rural areas of Spain, the beginning of the production specialisation processes and the integration of the Valencian agricultural sector into the markets in the mid-19 $9^{\text {th }}$ century did lead to an improvement in the biological standard of living of the populations of the irrigated area of Valencia. As described in the article, the intensive agriculture of Valencia offered greater employment opportunities and required more labour and capital, and although small family-run farms were the driving force, they generated higher levels of productivity and wealth. Therefore, there was a low incidence of emigration among the people from the irrigated area of and its economy displayed higher growth rates.

In addition to the evolution of height and the hypotheses regarding its determinants, during the period under study, we have identified two significant facts: first, that economic inequality (height inequality) diminished while the average biological well-being (average height) increased. This has been observed for the whole male population and also for the two rural groups analysed in the irrigated area of Valencia (farmers and farm workers). The second fact is the existence of biological inequalities depending on the socioeconomic status. The study of height in accordance with access to land ownership reveals that, at least from the mid- $19^{\text {th }}$ century, land-owning farmers were taller than landless farm workers. The disappearance of aristocratic privileges and the formation of a market society gave rise to social differences which were reflected essentially in the economic domain, depending on wealth. In addition to the landowners and different tenants, there was another social group which had no access to ownership; the landless farm workers. The estimates carried out have revealed that for the cohorts of the second-half of the $19^{\text {th }}$ century, the biological differences between land-owning farmers and landless farm workers were significant, while during the second period considered, the cohorts of the first-third of the $20^{\text {th }}$ century, these nutritional inequalities between the two rural groups were not significant.

\section{REFERENCES}

Ayuda, M. I., and Puche, J. (2014): «Determinants of Height and Biological Inequality in Mediterranean Spain, 1859-1967». Economics and Human Biology 15, pp. 101-119.

Baten, J. (2000a): "Heights and Real Wages in the $18^{\text {th }}$ and $19^{\text {th }}$ Centuries: An International Overview». Jarbuchfuer Wirtschaftsgeschichte 1, pp. 17-32. 
Baten, J. (2000b): «Economic Development and the Distribution of Nutritional Resources in Bavaria, 1797-1839». Journal of Income Distribution 9, pp. 89-106.

Beltrán, F. (2015): «Commons and the Standard of Living Debate in Spain, 1860-1930». Cliometrica 9 (1), pp. 27-48.

Blum, M. (2013): «The Influence of Inequality on the Standard of Living: Worldwide Anthropometric Evidence from the 19th and Centuries». Economics and Human Biology 11 (4), pp. 436-452.

Bodenhorn, H.; Guinnane, T. W., and Mroz, T. A. (2013): «Problems of Sample-Selection Bias in the Historical Heights Literature: A Theoretical and Econometric Analysis», Economics Department Working Paper No. 114, Yale University, Connecticut, USA. Available at http://www.econ.yale.edu/growth_pdf/cdp1023.pdf.

Bonmatí, J. F. (1989): La emigración alicantina a Argelia. Alicante: Universidad de Alicante.

BRINGAS, M. A. (2000): La productividad de los factores en la agricultura española (1752-1935). Madrid: Banco de España.

Calatayud, S. (1989a): Capitalismo agrario y propiedad campesina. La Ribera del Xúquer, 1860-1930. Valencia: Institut Alfons el Magnànim.

Calatayud, S. (1989b): «L'expansió citrícola valencana. Producció i propietat de la terra a la Ribera del Xúquer (1850-1930)». Recerques 22, pp. 95-115.

Calatayud, S. (2001): "Economía en transformación. Agricultura e industria en la época contemporánea (1800-1950)», in P. Preston, and I. Saz (eds), De la revolución liberal a la democracia parlamentaria: Valencia (1808-1975). Valencia: Biblioteca Nueva, pp. 163-200.

Calatayud, S.; Millán, J., and Cruz, M. (1992): «Les transformacions de la societat agrària en el procés de desenvolupament capitalista: el regadiu valencià el segle XIX». Recerques 25, pp. 125-138.

Calatayud, S., and Millán, J. (2010): «Las vías simultáneas del capitalismo agrario valenciano», in R. Garrabou (ed.), Sombras de progreso. Las huellas de la historia agraria. Barcelona: Crítica, pp. 199-229.

Calzado, A. (1995): «La negociación de salarios y condiciones laborales de los obreros agrícolas de Sueca y Cullera en la plantada y siega del arroz durante la II República». II Jornades D'Estudis de Cullera. pp. 213-233.

CÁmara, A. D. (2009): "Long-Term Trend in Height in Rural Eastern Andalusia (1750-1950)». Historia Agraria 47, pp. 45-67.

Carmona, J.; Rosés, J. J., and Simpson, J. (2015): «Spanish Land Reform in the 1930s: Economic Necessity or Political Opportunism?», EHES Working Paper in Economic History, No. 90, November 2015, pp. 1-27.

CARrión, P. (1973): La reforma agraria en la Segunda República. Barcelona: Ariel.

Clar, E., and Pinilla, V. (2009): «The Contribution of Agriculture to Spanish Economic Development, 1870-1973», in P. Lains, and V. Pinilla (eds), Agriculture and Economic Development in Europe Since 1870. London: Routledge, pp. 311-332.

Clar, E.; Martín-Retortillo, M., and Pinilla, V. (2016): "Agricultura y desarrollo económico en España, 1870-2000», in D. Gallego, L. Germán, and V. Pinilla (eds), Estudios sobre el desarrollo económico español. Zaragoza: Prensas de la Universidad de Zaragoza, pp. 165-209.

Ferrater, M. A., and Terol, V. (1996): «Malalties i población al País Valencià: la Ribera del Xúquer, 1819-1910», in J. L. Barona, and J. Micó (eds), Salut i malaltia en els municipis valencians. València: Seminari d’Estudis sobre la Ciència-Universitat de València, pp. 263-276.

Fogel, R. W.; Floud, R., Harris, B., and Hong, S. C. (2011): The Changing Body: Health, Nutrition, and Human Development in the Western World Since 1700. Cambridge: Cambridge University Press. 
Gallego, D. (1993): «Pautas regionales de cambio técnico en el sector agrario español (1900-1930)». Cuadernos Aragoneses de Economía III (2), pp. 241-276.

Gallego, D. (2001): "Historia de un desarrollo pausado: integración mercantil y transformaciones productivas de la agricultura española (1800-1936)», in J. Pujol, M. González de Molina, L. Fernández Prieto, D. Gallego, and R. Garrabou (eds), El pozo de todos los males. Sobre el atraso en la agricultura española contemporánea. Barcelona: Crítica, pp. 147-214.

Gallego, D., and Pinilla, V. (1996): «Del librecambio matizado al proteccionismo selectivo: el comercio exterior de productos agrarios en España entre 1849 y 1935 ». Revista de Historia Económica 2, pp. 371-420.

Garcia-Montero, H. (2009): "Antropometría y niveles de vida en el Madrid rural, 1837-1915». Historia Agraria 47, pp. 95-117.

Garrabou, R. (1985): Un fals dilema. Modernitat o endarreriment de l'agricultura valenciana (1850-1900). Valencia: Institut Alfons El Magnànim.

GARRABOU, R., and SANZ, J. (1985): «La agricultura española durante el siglo XIX, ¿inmovilismo o cambio?», in R. Garrabou, and J. Sanz (eds), Historia agraria de la España contemporánea. Barcelona: Crítica, Tomo II, pp. 7-191.

Garrabou, R., and Pujol, J. (1988): «La especialización de la agricultura mediterránea y la crisis. Cataluña y el País Valenciano», in R. Garrabou (ed.), La crisis agraria de fines del siglo XIX. Barcelona: Crítica, pp. 94-130.

Garrabou, R.; Planas, J., Saguer, E., and Vicedo, E. (2014): «Propiedad de la tierra y desigualdad social en el mundo rural catalán de mediados del siglo XIX». Historia Agraria 63, pp. 115-150.

GARRIDO, S. (1999): «El conreu del taronger a la Plana de Castelló: agricultura comercial, propietat pagesa i treballas salariat (1850-1930)». Estudis d'Història Agrària 13, pp. 201-227.

GarRIDo, S. (2004): Canem Gentil. L'evolució de les estructures agraries a la Plana de Castelló (1750-1930). Castelló: Ajuntament de Castelló.

GozÁLVEz, V. (2003): «Natalidad y mortalidad de la población valenciana (1858-1960)». Cuadernos de Geografía 77/74, pp. 277-302.

Hernández, R., and Moreno-Lázaro, J. (2009): «El nivel de vida en el medio rural de Castilla y León. Una constatación antropométrica». Historia Agraria 47, pp. 143-166.

Heyberger, L. (2007): «Toward an Anthropometric History of Provincial France, 1780-1920». Economics and Human Biology 5, pp. 229-254.

Komlos, J. (2004): «How to (and How Not to) Analyze Deficient Height Samples: An Introduction». Historical Methods 37 (4), pp. 160-173.

Komlos, J. (2009): "Anthropometric History: An Overview of a Quarter Century of Research». Anthropologischer Anzeiger 67 (4), pp. 343-356.

LEEUven, M. H. D., and MaAs, I. (2011): HISCLASS. A Historical International Social Class Scheme. Leuven: Leuven University Press.

María-Dolores, R., and Martínez-Carrión, J. M. (2011): «The Relationship Between Height and Economic Development in Spain, 1850-1958». Economics and Human Biology 9, pp. 30-44.

Martínez-Carrión, J. M. (1986): «Estatura, nutrición y nivel de vida en Murcia, 1860-1930». Revista de Historia Económica 4 (1), pp. 67-99.

MartíneZ-Carrión, J. M. (ed.) (2002a): El nivel de vida en la España rural. Siglos XVIII-XX. Alicante: Universidad de Alicante.

MartíneZ-Carrión, J. M. (2002b): «El nivel de vida en la España rural, siglos XVIII XX. Nuevos enfoques, nuevos resultados», in J. M. Martínez Carrión (ed.), El nivel de vida en la España rural, siglos XVIII-XX. Alicante: Universidad de Alicante, pp. 15-72. 
Martínez-Carrión, J. M. (2014): «Stature, Welfare, and Economic Growth in NineteenthCentury Spain: The Case of Murcia», in R. Fogel,R. Floud, B. Harris, and S. Hong (eds), Health, Mortality and the Standard of Living in Europe and North America Since 1700. Volume II, Part I Cheltenham, UK: Edward Elgar Publishing.

Martínez-Carrión, J. M. (2016): «Living Standards, Nutrition and Inequality in the Spanish Industrialisation. An Anthropometric View». Revista de Historia Industrial 64, pp. 11-50.

Martínez-Carrión, J. M., and Pérez-Castejón, J. J. (2002): «Creciendo con desigualdad. Niveles de vida biológicos en la España rural mediterránea desde 1840», in J. M. Martínez-Carrión (ed.), El nivel de vida en la España rural. Siglos XVIII-XX. Alicante: Universidad de Alicante, pp. 405-460.

Martínez-Carrión, J. M., and Moreno-Lázaro, J. (2007): «Was there an Urban Height Penalty in Spain, 1840-1913?». Economics and Human Biology 5, pp. 144-164.

Martínez-Carrión, J. M., and Puche, J. (2009): «Alfabetización, bienestar biológico y desigualdad: la Comunidad Valenciana, 1850-1970». Historia Agraria 47, pp. 167-186.

Mateu, E., and Calatayud, S. (1996): «La evolución de la agricultura valenciana: algunos aspectos (1840-1930)», in J. Azagra, E. Mateu, and J. Vidal (eds), De la sociedad tradicional a la Economía moderna. Estudios de Historia Valenciana Contemporánea. Alicante: Instituto Juan Gil-Albert, pp. 101-124.

Moreno-Lázaro, J., and Martínez-Carrión, J. M. (2009): «La evolución de la estatura en una región atrasada de la España interior: Castilla y León, 1830-1960». Hispania 231, pp. 209-234.

Nicolau, R. (2005): «Población, salud y actividad», in A. Carreras, and X. Tafunell (eds), Estadísticas Históricas de España. Barcelona: FBBVA, pp. 77-154.

O'Brien, P., and Prados DE LA Escosura, L. (1992): "Agricultural Productivity and European Industrialization, 1890-1980». Economic History Review 45 (3), pp. 514-536.

Palafox, J. (2001): «La tardía industrialización de la economía valenciana», in L. Germán, E. Llopis, J. Maluquer de Motes, and S. Zapata (eds), Historia económica regional de España. Siglos XIX y XX. Barcelona: Crítica, pp. 390-412.

Pérez-Castroviejo, P. M. (2016): «Biological Welfare During the Economic Development of the Basque Country: Biscay, 1850-2000». Revista de Historia Industrial 64, pp. 183-212.

PIQUERAS, J. (1985): La agricultura valenciana de exportación y su formación histórica. Madrid: Ministerio de Agricultura.

Pioueras, J. (1999): El espacio valenciano. Una síntesis geográfica. Valencia: Gules.

Pinilla, V. (1995): "Cambio agrario y comercio exterior en la España contemporánea». Agricultura y Sociedad 75, pp. 173-179.

Pinilla, V., and Ayuda, M. I. (2008): «Market Dynamism and International Trade: A Case Study of Mediterranean Agricultural Products, 1850-1935». Applied Economics 40 (5), pp. 585-595.

Pinilla, V., and Ayuda, M. I. (2009): «Foreign Markets, Globalization and Agricul-tural Change in Spain 1850-1935», in V. Pinilla (ed.), Markets and Agricultural Change in Europe from the Thirteenth to the Twentieth Century. Turnhout, Belgium: Brepols Publisher, pp. 173-208.

Pinilla, V., and Ayuda, M. I. (2010): «Taking Advantage of Globalization? Spain and the Building of the International Market in Mediterranean Horticultural Products, 1850-1935». European Review of Economic History 14, pp. 239-274. 
Puche, J. (2011): «Evolución de los niveles de vida biológicos en la Comunidad Valenciana, 1840-1948». Investigaciones de Historia Económica 7 (3), pp. 380-394.

Puche, J., and Cañabate-Cabezuelos, J. (2016): «Did physical stature diminish during Spain's early industrialization? The case of Alcoy, 1840-1915». Revista de Historia Industrial 64, pp. 119-147.

Pujol, J.; González, D. E., Molina, M., Fernández Prieto, L., Gallego, D., and Garrabou, R. (2001): El pozo de todos los males. Sobre el atraso en la agricultura española contemporánea. Barcelona: Crítica.

Ramon-Muñoz, J. M. (2009): «Bienestar biológico y crecimiento agrario en la Cataluña rural, 1840-1936». Historia Agraria 47, pp. 119-142.

Ramon-Muñoz, J. M. (2013): "Cambio agrario, uso del suelo y regadío: el impacto del Canal de Urgell, 1860-1935». Historia Agraria 59, pp. 43-94.

Sanz Gimeno, A., and Ramiro Fariñas, D. (2002): "Infancia, mortalidad y niveles de vida en la España interior. Siglos XIX y XX», in Martínez Carrión, J. M. (ed.), El Nivel de Vida en la España Rural, Siglos XVIII-XX. Alicante: Universidad de Alicante, pp. 359-403.

Silvestre, J. (2005): «Internal Migrations in Spain, 1877-1930». European Review of Economic History 9 (2), pp. 233-265.

Silvestre, J.; Ayuda, M. I., and Pinilla, V. (2015): "The Occupational Attainment of Migrants and Natives in Barcelona, 1930». The Economic History Review 68 (3), pp. 985-1015.

Simpson, J. (1994): «La producción y la productividad agraria españolas, 1890-1936». Revista de Historia Económica XII (1), pp. 43-81.

SpiJker, J.; CÁmara, A. D., and Blanes, A. (2012): «The Health Transition and Biological Living Standards: Adult Height and Mortality in 20th-Century Spain». Economics and Human Biology 10, pp. 276-288.

Steckel, R. (2009): "Heights and Human Welfare: Recent Developments and New Directions». Explorations in Economic History 46, pp. 1-23. 


\section{APPENDIX}

FIGURE A1

DISTRIBUTION OF THE HEIGHTS OF THE CONSCRIPTS MEASURED IN THE IRRIGATED AREA OF VALENCIA, RECRUITS OF 1879-1920 (BIRTH COHORTS OF 1859-99)

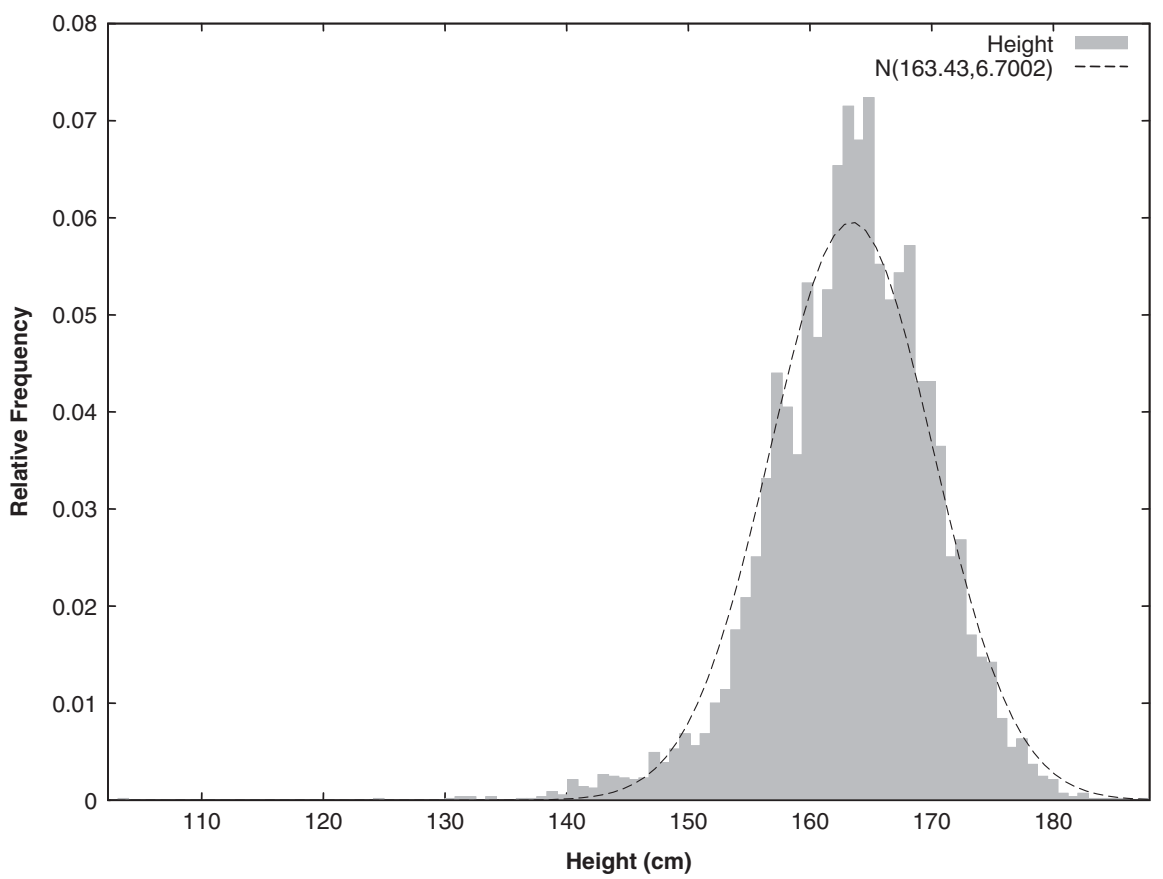

Source: Conscription and call-up records; historical municipal archives from Valencian municipalities composing the anthropometric sample. 
FIGURE A2

DISTRIBUTION OF THE HEIGHTS OF THE CONSCRIPTS MEASURED IN THE IRRIGATED AREA OF VALENCIA, RECRUITS OF 1921-60 (BIRTH COHORTS OF 1900-39)

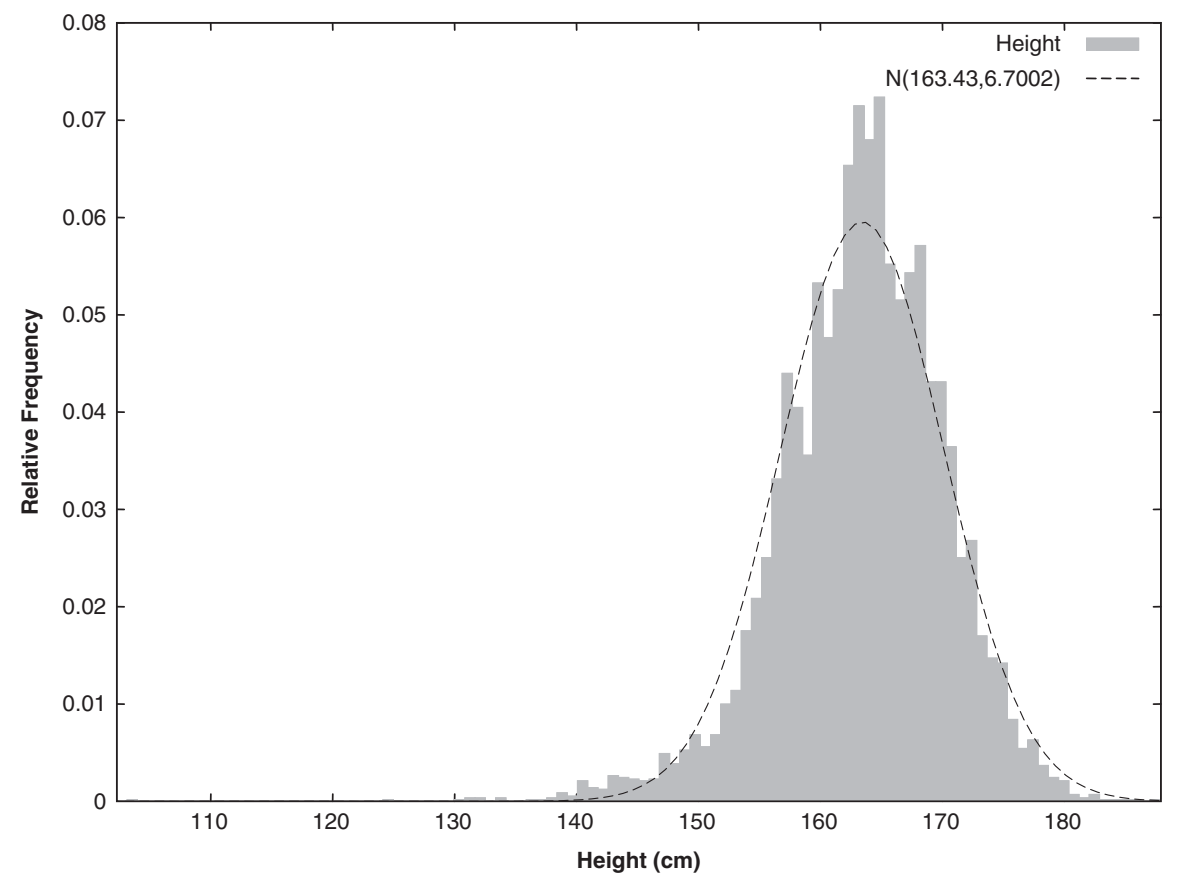

Source: Conscription and call-up records; historical municipal archives from Valencian municipalities composing the anthropometric sample. 